Available online at http://jgu.garmian.edu.krd

Journal of University of Garmian

https://doi.org/10.24271/garmian.21080102

\title{
التفاعل الاجتماعي وعلاقته بالتحصيل الدراسي لدى طلبة جامعة كرميان \\ ( دراسـة ميدانية في كلية التربية )
}

\author{
شوان فرج سعيد \\ كلية التربية- جامعة كرميان- إقليم كوردستان العراق سعيل
}

\section{Article Info}

Received: April, 2021

Accepted :June,2021

Published :July ,2021

\section{Keywords}

التفاعل الاجتماعي - التحصيل الدراسي، طلبة جامعة كرميان

\section{Corresponding Author}

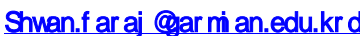

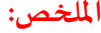

تهدف الدراسة الكشف عن التفاعل الاجتماعي وعلاقته بالتحصيل الدراسي لدى طلبة كلية التربية الاقسام العلمية جامعة كرميان، من خلال السؤال الرئيسي الاتي: ما العلاقة بين التفاعل الاجتماعي والتحصيل الدراسي لدى الطلبة ؟ والذي تنبثق منه الأسئلة الفرعية الاتية:

1. هل التعاون بين الطالب وزملائه يساهم في التحصيل الدراسي في المرحلة الجامعية؟

2. هل التكيف بين الطالب وزملائه يساهم في التحصيل الدراسي في المرحلة الجامعية ؟

3. هل التنافس بين الطالب وزملائه يساهم في التحصيل الدراسي في المرحلة الجامعية ؟ ولإِجابة عن التساؤلات التالية قمنا بوضع فرضيات متمثلة في:

التعاون بين الطالب وزملائه يساهم في التحصيل الدراسي لدى طلبة كلية التربية الأقسام

$$
\text { العلمية. }
$$

التكيف بين الطالب وزملائه يساهم في التحصيل الدراسي لدى طلبة كلية التربية الأقسام

$$
\text { العلمية. }
$$

التنافس بين الطالب وزملائه يساهم في التحصيل الدراسي لدى طلبة كلية التربية الأقسام

$$
\text { العلمياة. }
$$

ولقد أقتضت طبيعة الدراسة إتباع المنهج الوصفي، مع الاستعانة بمجموعة من التقنيات البحثية للحصول على المعطيات الميدانية، المقابلة وغيرها حيث كان الاستبيان من أبرزها، وطبق على عينة الدراسـة، يتكون مجتمع الدراسة من طلبة كلية التربية الاقسام العلمية جامعة كرميان، وبلغت حجم

$$
\text { العينة (147) طالبا وطالبة، وخلصت الى النتائج الاتية: }
$$

تحقق الفرضية الاولى أي ان التعاون بين الطالب وزملائه يساهم في التحصيل الدراسي.

صدق الفرضية الثانية أيالتكيف بين الطالب وزملائه يساهم في التحصيل الدراسي.

صداق الفرضية الثالثة أي التنافس بين الطالب وزملائه يساهم في التحصيل الدراسي عند الطلبة. 
أما الطالب الذي لا يتقبل نفسه ولايشعر بالرضا وعدم تكيفه اجتماعياً يدفعه نحو الانطواء ويؤثر على تحصيله الدراسي. وفي بحثنا هذا نحاول توضيح العلاقة بين التفاعل الاجتماعي والتحصيل الدراسي لدى طلبة كلية تلية لئل التربية الأقسام العلمية جامعة كرميان من خلال السؤال الرئيسي الاتي: ماالعلاقة بين التفاعل الاجتماعي والتحصيل الدراسي لدى طلبة كلية التربية الأقسام العلمية

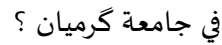
والذي تنبثق منه الأسئلة الفرعية الاتية: هل التعاون بين الطالب وزملائه يساهم في التحصيل الدراسي في المرحلة الجامعية؟ هل التكيف بين الطالب وزملائه يساهم في التحصيل الدراسي في المرحلة الجامعية ؟ هل التنافس بين الطالب وزملائه يساهم في التحصيل الدراسي في المرحلة الجامعية ؟ أهمية البحث: Research Significance اختيارنا لهذا الموضوع في بحثنا هذا ينبع من إِيماننا بالدور الذي تقوم به المؤسسات الاكاديمية

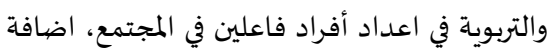

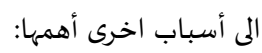
المساهمة في البحث والتحليل في كيفية رفع مستوى الحرى التحصيل الدراسي. المساهمة في خلق مناخ تعليمي أفضل لتحصيل

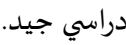
الدور الفعال للتفاعل الاجتماعي داخل المؤسسات الاكاديمية والتربوية في عملية التحصيل الدراسي. أهداف البحث: Research Objectives :

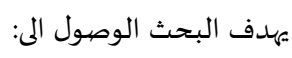

معرفة طبيعة العلاقة بين التعاون والتحصيل الدراسي لدى طلبة كلية التربية الأقسام العلمية

$$
\text { في جامعة 'كرميان. }
$$

مشكلة البحث وأسئلته: Research Problem Questions

تقدم كل مجتمع وأساس بنائها وحضارتها هي التربية والتعليم، ولايمكن تحقيق هذا التقدم الران

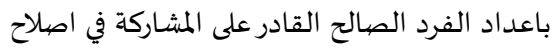

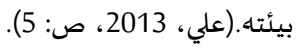

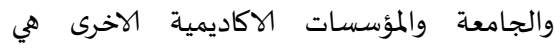
مؤسسات علمية أكاديمية أوجدها المجتمع لتحقيق الاكاديه أهدافه والمتمثلة في اعداد الفرد (الانسان) للحياة، وهي ليست منعزلة عن الهيكل الاجتماعي العام وتقوم بنقل الثقافة والعلم ومشاركها في عملية التماسك الاجتماعي ووحدتها وتوحيد الجهود نحو التطور والبناء واعداده للتعامل مع العالم المادي والنفسي والاجتماعي وتوجيها توجيهاً سليماً نحو

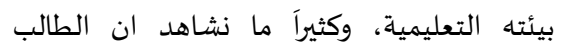

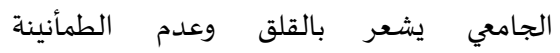
والاضطرابات النفسية عندما لا يتكيف مع المواد

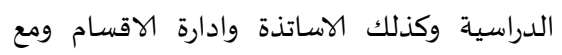
الزملاء، مما تؤثر هذه المشكلات على نفسية الطالب وتحصيله الدراسي، ولهذا ولتحقيق التكييف النفسي والاجتماعي له، يجب على البيئة التعليمية مراعاة الاساليب التربوية والبيداغوجيا السليمة من اجل تكوين فرد (طالب) تكويناً معرفياً وسيكولوجياً للتكييف والتوافق مع محيطه. العلاقات الاجتماعية وخاصة العلاقات الجامعية تؤدي الي حدوث مجموعة من التغيرات النفسية

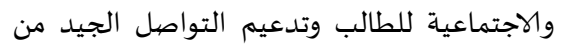

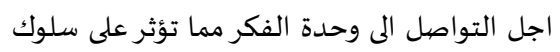

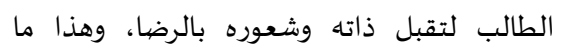
يدفعه الى العمل الجاد والتوافق مع الاخرين والانجاز في مجالات تتفق مع ميوله وامكانياته لئه وبالتالي التفوق في التحصيل الدراسي. 
التعريف الاجرائي: هو ما يحدث عند اتصال فرد بفرد أو مجموعة من الافراد والذي يترتب عنه التأثير المتبادل أو تعديل السلوك في جامعة كرميان. التحصيل الدراسي: يعرفه: (سمارة وعبدالسلام، 2008) بانه: المعلومات والمهارات المكتسبة من قبل المتعلمين كنتيجة لدراسة موضوع أو وحدة دراسية محددة (سمارة

$$
\text { وعبدالسلام، 2008، ص:52). }
$$

و عرفته (الجلالي، 2011) بأنه: مفهوم يتحدد من منال خلال مستوى الأداء الفعلي للفرد في المجال الأكاديمي الناتج عن عملية النشاط العقلي المعرفي للطالب ويستدل عليه من خلال إجاباته على مجموعة من الاختبارات (الجلالي، 2011،ص: 25). التعريف الاجرائي: هو مجموعة المعارف التي تقدر بعلامات الطلبة (درجات الطلبة) (طلبة كلية التربية) أي (أفراد العينة)والتي توجد في سجلات الأقسام. جامعة كرميان: جامعة حكومية عراقية تقع في اقليم كوردستان العراق، تأسست في شهر اذار لعام 2010، تتكون الجامعة من كليات (الطب،

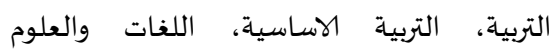

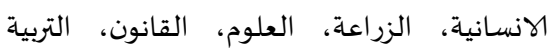
الرياضية، الهندسة). (www.garmian.edu.krd).

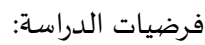
تعتبر الفروض هي التي تحدد الاتجاهات التي يمكن البحث فيها، حيث لا يمكن أن نسير خطوات البحث ما لم نبدأ بتفسير مقترح للظاهرة أو مشكلة

$$
\text { موضوع البحث (صابر و حفاجة، 2002، ص:72). }
$$

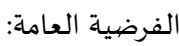
توجد علاقة بين التفاعل الاجتماعي والتحصيل الدراسي لدى طلبة كلية التربية الأقسام العلمية في جامعة كرميان.

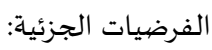

التعاون بين الطالب وزملائه يساهم في التحصيل الدراسي لدى طلبة كلية التربية الأقسام العلمية
معرفة طبيعةالعلاقة بين التكيف والتحصيل الدراسي لدى طلبة كلية التربية الأقسام العلمية في جامعة كرميان. معرفة طبيعة العلاقة بين التنافس والتحصيل الدراسي لدى طلبة كلية التربية الأقسم العلمية في جامعة كرميان .

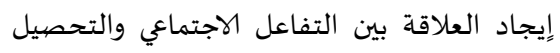
الدراسي لدى طلبة كلية التربية الأقسام العلمية في جامعة كرميان. حدود البحث: Research Limits الحدود الموضوعية: دراسة الكشف عن طبيعة

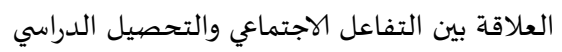
لدى طلبة كلية التربية الأقسام العلمية جامعة كرميان. الحدود الزمانية: طلبة كلية التربية الأقسام العلمية/ جامعة كرميان للعام الدراسي 20192020

الحدود المكانية: طبيعة العلاقة بين التفاعل الاجتماعي والتحصيل الدراسي لدى طلبة كلية التربية الأقسام العلمية جامعة كرميان. الحدود البشرية: يتحدد البحث الحالي بطلبة كلية

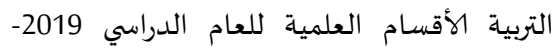

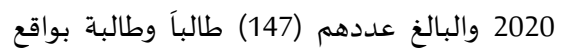
(104) طالبة و(43) طالب. تعريف المصطلحات: Term Definitions التفاعل الاجتماعي: وهو العملية التي يرتبط بهما اعضياء الجماعة بعضهم مع بعض عقلياً ودافعياً

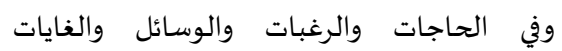
والمعارف وما شابه ذلك (المعايظة، 2007،ص:

وعرفه (نصرالدين والهاشمي،1706): وهي العملية

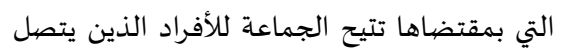

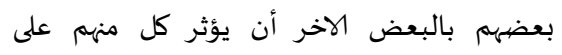

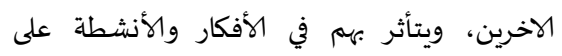
السواء (نصرالدين والهاشمي، 2006، ص:55). 
الفرد في سلوكه الاجتماعي والتي تدعى بالسمات التفاعلية والسمات الوولية للاستجابات الشخصية المتبادلة (كرش واخرون، 1974، ص:220) المشار

$$
\text { اليه في (علي، 2013، ص:120). }
$$

يسهم التفاعل الاجتماعي في تكوين سلوك الانسان، فمن خلاله يكتسب الوليد البشري خصائصها الانسانية ويتعلم لغة قوماه وثقافة مجتمعاه وقيمها وعاداتها وتقاليدها، من خلال عملية التطبع الاجتماعي (عبادة، 2014، ص:26) ومنها: التفاعل الاجتماعي ضروري لنمو الطفل، فلقد بينت الدراسات أن الطفل الذي لا تتوفر له فرصية كافية للتفاعل الاجتماعي يتأخر نموه. يهيء التفاعل الاجتماعي الفرص للاشخاص ليتميز كلا منهم بشخصيته- ذاتيته - فيظهر منهم المخططون، المبدعون، وكذلك العدوانيون... كما يكتسب المرء القدرة على التعبير والمبادرة

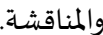

يعد التفاعل الاجتماعي شرطاً أساسياً لتكوين الجماعة، اذ ترى نظرية التفاعل الاجتماعي أنها نسق من الاشخاص يتفاعل بعضهم مع بعض، مما يجعلهم يرتبطون معا في علاقات معينة ويكون كل منهم على وعي بعضويته في الجماعة، ومعرفة ببعض أعضائها، ويكونون تصوراً مشتركاً (مجموعتهم. يؤدي التفاعل الاجتماعي الى تمايز شرائح الجماعة فتظهر القيادات وعكس ذلك. يساعد التفاعل الاجتماعي على تحديد الأدوار الاجتماعية أو المسؤوليات التي يجب أن يضطلع بها لهاعل كل انسان، ففي جماعات المناقشة مثلاً يؤدي التفاعل الى ابراز أدوار المشاركين وتعميقها. (علي،

$$
\text { 2013، ص:26). }
$$

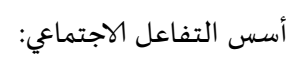

يقوم التفاعل الاجتماعي على الأسس أو المحددات
التكيف بين الطالب وزملائه يساهم في التحصيل الدراسي لدى طلبة كلية التربية الأقسام العلمية التنافس بين الطالب وزملائه يساهم في التحصيل الدراسي لدى طلبة كلية التربية الأقسام العلمية الفصل الثاني - الني الإِطار النظري والدراسات السابقة: أولاً: الاطار النظري: التفاعل الاجتماعي هو احدى المهارات التي على النى

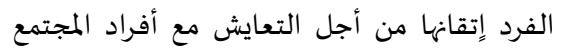
الذي ينتمي اليه، فالمجتمع يسند اليه أدواراً متعددة ومتباينة قد ينجح أو يفشل بدرجات متفاوتة في أدائها، وذلك حسب عدد عدد من المتغيرات مثل جنس الفرد، مكانته الاجتماعية، قدراته الذاتية، والمهارات الاجتماعية التي يمتلكها وكذلك حسب طبيعة الموقف. يعد التفاعل الاجتماعي بشكل عام نوعاً من المؤثرات والاستجابات، وفي العلوم الاجتماعية يشير الى سلسلة من المؤثرات والاستجابات ينتج عنها

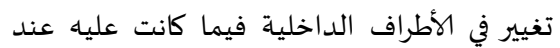
البداية، والتفاعل الاجتماعي لا يؤثر في الأفراد فحسب بل يؤثر كذلك في القائمين على البرامج

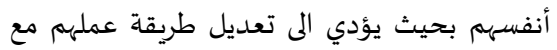

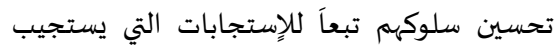
لها الأفراد ( الشناوي وأخرون، 2001، ص:65).

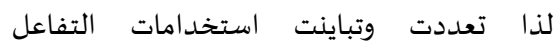
الاجتماعي فهو مثلاً: يستخدم كعملية (process): لأنه يتضمن نوعاً من النشاط الذي تستثيره حاجات معينة عند الانسان كالحاجة للانتماء، الحاجة للحب، والحاجة للتقدير

$$
\text { والنجاح. }
$$

وهو حالة (State): لأنه يستخدم في الاشارة الى النتيجة النهائية التي يترتب علها تحقيق هذه

$$
\text { الحاجات عند الانسان. }
$$

وهو مجموعة من الخصائص (Traits): والتي هي نوع من الاستعدادات الثابتة نسبياً، تميز استجابات 
يفسر من خلال قيامه بالادوار الاجتماعية المختلفة أثناء تفاعله مع الاخرين طبقاً لخبرته التي أكتسبها وعلاقته الاجتماعية، فالتفاعل بين الافراد يتحدد وفقاً للادوار المختلفة التي يقومون بها (الشناوي

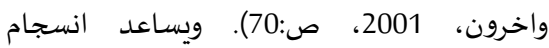

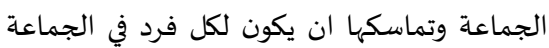
دور يؤديه مع قدرته على تمثيل أدوار الاخرين داخلياً، يساعد ذلك على ادراك عملية التوقع السابق ذكرها، اذ ان الشخص الذي يقوم بنشاط في الجماعة ويعجز عن توقع افعال الاخرين، لعجزه عن ادراك ادوارهم وعلاقة دوره بدورهم لن يتمكن

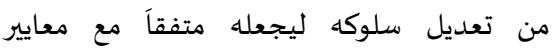
الجماعة (حسن، 1998، صن: 18). الرموز الدلالة: يتم الاتصال والتوقع ولعب الادوار بفاعلية عن طريق الرموز ذات الدلالة المشتركة

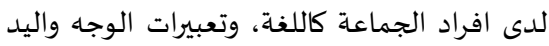

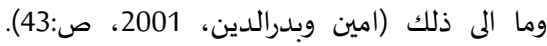
ويشير يونغ (Young) الى ان الانسان يعيش في عالم من الرموز، هي شكل من اشكال التعبير عن الافكار

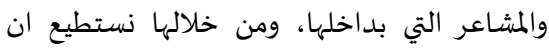
نعبر عن خبرتنا (الشناوي واخرون، 2001، ص:

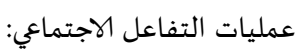

يرتبط الأفراد بعضهم ببعض عن طريق التفاعل فيما بيههم، وهذا يتسم بطرق او عمليات تؤدي وتمارس في المجتمع، ويطلق عليها اسم العمليات الاجتماعية وهي: عبارة عن أنماط سلوكية متكررة

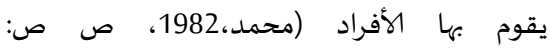

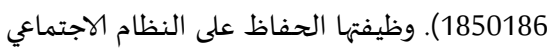
والعمل على نموه وإتساع حجماه، وتشمل ثلاثة مستويات: تفاعل فرد مع فرد، وتفاعل مجموعة أفراد مع اخرين في نفس الجماعة، وتفاعل الجماعة كمجتمع مع جماعة اخرى ( ابراهيم، 1966، ص:105). ومن العمليات الاجتماعية التي
الاتصال: لايتحقق تفاعل اجتماعي بطبيعة الحال

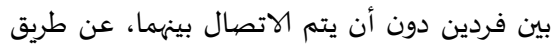

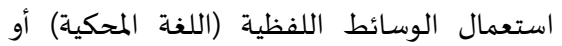
باستخدام وسائط غير لفظية، وتكون مثيراً لاستجابات حركية كالإيحاءات والشارات ......

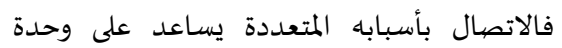
الفكر، والتوصل الى الى السلوك التعاوني (حسن،

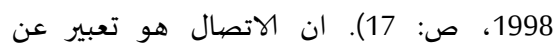
العلاقات بين الافراد، ويعني نقل فكرة معينة أو انو

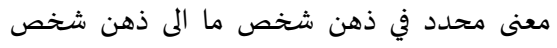

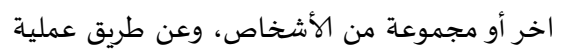
الاتصال يحدث التفاعل الاجتماعي بين الافراد، ولايمكن أن تحدث عملية الاتصال أو تتحقق بلان الاهرداد لذاتها، ولكنها تحدث من حيث هي أساس عملية التفاعل الاجتماعي، حيث يستحيل فهم ودراسة عملية التفاعل في أية مجموعة دون التعرف على حماتل عملية الاتصال بين أفرادها (امين وبدرالدين، 2001، ص: 38).

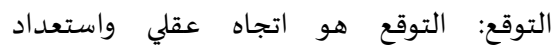

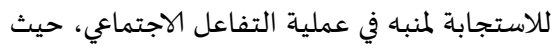

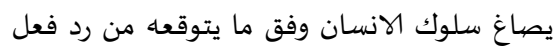

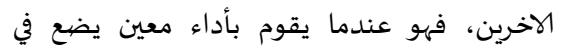

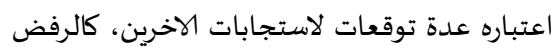

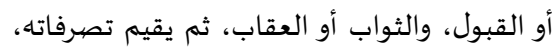
ويكيف سلوكه طبقاً لهذه التوقعات (صالح، 1985، ص:127). ويبنى التوقع على الخبرات

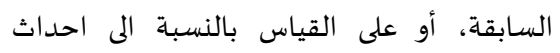

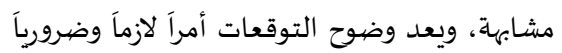
لتنظيم السلوك الاجتماعي في أثناء عمليات التفاعل، كما يؤدي غموضها الى عملية التلائم مع التماء سلوك الاخرين أمراً صعباً يؤدي الى الشعور بالعجز الئز عن الاستمرار في انجاز السلوك المناسب (توفيق المرن وبلقيس، 1984، ص:125). ادراك الدور وتمثيله: لكل فرد دور يقوم به، وهذا لها الدور يفسر من خلال السلوك، فسلوك الفرد 
العلمية، ويلعب التنافس دوراً في ضبط المجتمع لأن المتنافسين يخضعون لأطر وقوانين وقواعد

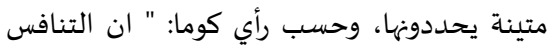

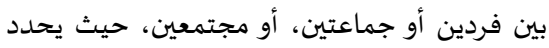

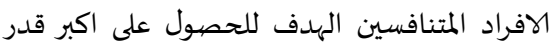
منه، ويتفق الافراد على التنافس الشريف لتحقيق الهدف المنشود (العتوم، 2008، ص صنى صلادئ 302-

الصراع: وهو حالة نفسية مؤلمة تنشأ نتيجة

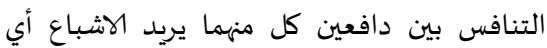
ينشأ نتيجة تعارض دافعين لا يمكن في وقت واحد، اذن الصراع سمة من سمات الحياة فالانسان منذ ولادته وحتى موته يقع في صراع ينشأ في الرغبة الأكيدة في إشباع الدوافع، فقد ينشأ الصراع بين رغباتنا وبين معايير المجتمع التي تقع حائلاً دون

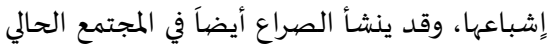
وما يعتز به من كثرة الأدوار التي قد يتعارض بعضها البعض وهناك علاقة أكيدة بين الصراع والإحباط فالإحباط وجود عقبة تحول دون اشباع دوافع واحد، أما الصراع فهو التعارض بين إِشباع دافعين قد يكون أحد دوافع الإحباط أحداً منهما (العتوم، إنهاع 2009، ص: 294).

التكيف: انه عملية اجتماعية تعمل على اضعاف

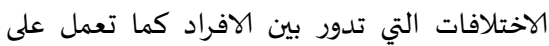
زيادة مظاهر الوحدة، وتوحيد الاتجاهات، وورد

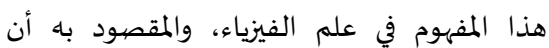
الجسم يقوم بعملية تمثل المواد العذائية التي

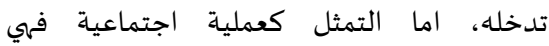
امتصاص الاختلافات وحل النزاعات وعودة روح المحبة والتعاون بين الافراد انه القدرة على تكوين العلاقات المرضية بين الفرد وبيئته للحصول على بلى الحئ الاستقرار النفسي والبدني، وتبدأ عملية التكيف منذ الولادة، حيث يبدأ الوليد مع البيئة الطبيعية والاجتماعية، وعندما تتغير الظروف الخارجية فان
تحدث ضمن اطار اجتماعي هي التعاون والتنافس، الصراع والتكيف التعاون: إِن التعاون هو القيام بِإنشطة مترابطة

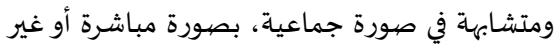

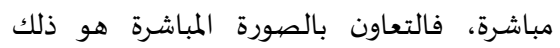
التعاون الذي يقوم على انجاز الانشطة غير بهره المتشابهة والتي يكمل بعضها بعضا، وتؤدي جميعها

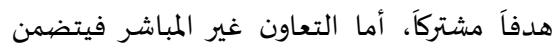
تقسيماً للعمل وأداء لمهام متخصصية وبهذا فان مان

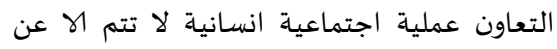
طريق العمل الجماعي بين الافراد لتحقيق أهداف

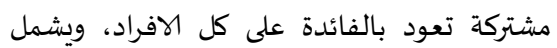
التعاون كافة المجالات الاقتصادية، الاجتماعية والسياسية (محمد، 1982، ص ص: 187-192). التنافس: إنها عملية اجتماعية بإعتباره يحدث بين افراد المجتمع، فهو تقليد الانسان لغيره لكي لا لان لانسان يكون دونه، ويحدث التنافس بين طرفين يسعى كل لهيل منهما لتحقيق الهدف الذي يسعى اليه الطرف الاخر، وتعمل الاطراف المتنافسة بصورة مستقلة عن بعضها بعضا، وتكون الاطراف الى حد ما متماثلة في الصفات (محمد، 1982، ص: 210). ويسود السلوك التنافسي على صعيد الافراد: حسب درجة مستوى الطموح، فهم يعتقدون انهم

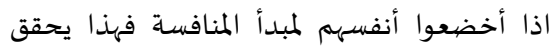
لهم النجاح والتفوق، أما على صعيد المجتمع: فيسود السلوك التنافسي في حالة ندوة المواد

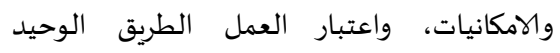
لتحقيق الاهداف الشخصية، أما على صعيد

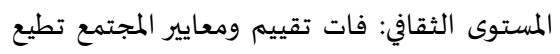
سلوك الافراد بطابعها الخاص ليوافق سلوكهم قيم ومعايير المستوى الثقافي للمجتمع (ابراهيم،

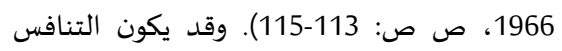
ايجابياً أو سلبياً حسب الفائدة التي يجنهيا الفرد

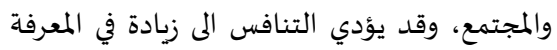
والرقى الفكري والتطور التكنولوبي، والإِتراعات 
النمط من السلوك عبارة المصادقة الِرضائية.

(ميلود، 2011، ص:87).

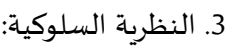

بلور السلوكيون عملية التفاعل الاجتماعي بين الأفراد الى نظرية المثير والاستجابة ونظرية التعزيز التي قادها سكنر، ويرى هؤلاء أن المخلوقات الاجتماعية ليست سلبية في تفاعلها بل أههم يستجيبون للتأثير والمنههات التي يتلقونها خلال

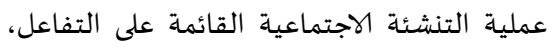

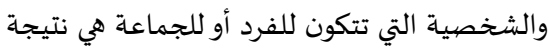
مباشرة لهذا التفاعل والتفاعل بهذا المعنى يتمثل في

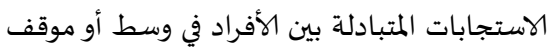
اجتماعي بحيث سلوك الواحد يكون مؤثراً أو منبهاً

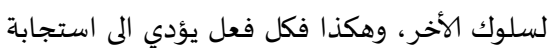
واستجابات في إطار عملية تبادل المنبهات. ويرى

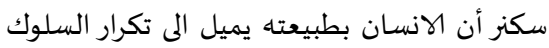
أو الاستجابة التي تحقق له هدفاً أو تلبي حاجة لهران

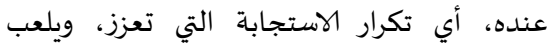

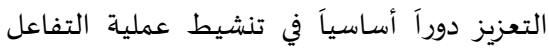

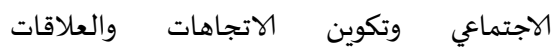
الاجتماعية. ويشير أصحاب هذه النظرية سكنر وجانييه الى أن عملية النماء الاجتماعي هي حصيلة تعلم أنماط السلوك المختلفة التي تعززها فتتابع

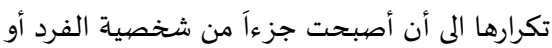

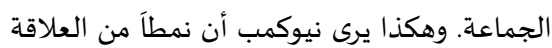
المتوازنة يسود بين شخصين متفاعلين عندما

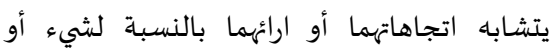

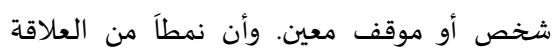

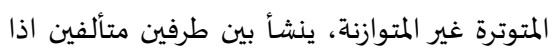

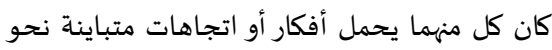
طرف ثالث مشترك وينشأ كذلك نمط من العلاقة غير المتوازنة بين الطرفين الغير متألفين حتى ولو كانا

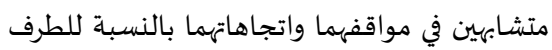
الثالث ويقول نيوكمب أن استعادة التوازن مرهون
الانسان يعدل من سلوكاه، ويكتشف طرقاً جديدة

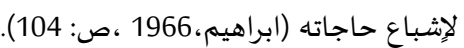

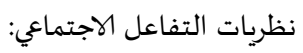
1. نظرية نيوكمب والتفاعل الاجتماعي ينظر (نيوكمب) الى التفاعل الاجتماعي وكأنه نظام

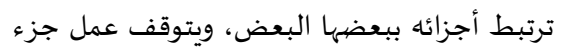

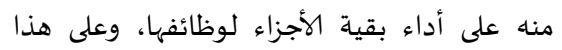

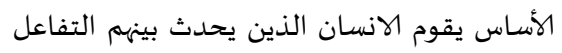
بتغيير سلوكهم نتيجة لهذا التفاعل حيث يعتدل سلوك أحد الطرفين إذا حدث تغيير في سلوك الطرف الاخر. ان نمطاً من العلاقة المتوازنة تسود احداد بين شخصين متفاعلين عند تشابه اتجاهاتهما وارائهما بالنسبة لشيء أو شخص أو موقف وان نمطاً من العلاقة المتوترة غير المتوازنة ينشاً بين المباء

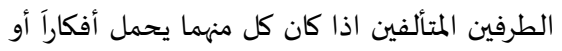
اتجاهاً متبايناً نحو طرف ثالث مشترك. كما ينشأ

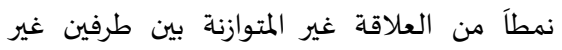
متألفين حتى ولو كانا متشابهين في مواقفهما واتجاهاتهما بالنسبة للطرف الثالث. وهكذا يستنتج (نيوكمب) ان مدى الصداقة والود والتجاذب تقوى بين الطرفين الذين تربطهما موقف واتجاهات

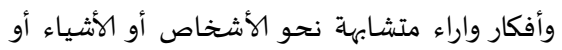
الموقف والراء ذات الاهتمام المشترك. (غيث، 1980، ص:116).

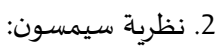
يميل أو يتجه الفرد الى تغيير احكامه في المواقف الغير متوازنة والتي يسودها التوتر أكثرمنه في

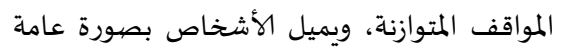
الى إصدار أحكام متشابهة لمن يحبون أو يألفون،

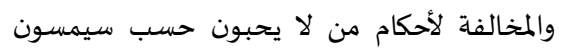

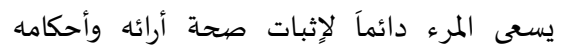
ومعتقداته، ومواقفه الاجتماعية عن طريق تمثيلها عند أشخاص أخرين في مجتمعه خاصة مما يميل الههم بالنسبة لأشياء أو مواقف أو قيم معينة، ويطلق علماء علم النفس الاجتماعي على هذا الهاء 
التقصير الملحوظ عن بلوغ مستوى معين من

التحصيل الذي تعمل المدرسة من أجله وهذا ما يعرف بالتأخر الدراسي (الدمنهوري واخرون،

2005، ص: 189 (189).

يعتبر التحصيل الدراسي للطلبة في مختلف مستوياتهم التعليمية، الهدف الاساسي لكل فعاليات العملية التعليمية، وتتمثل أهداف التحصيل الدراسي في النقاط الاتية: يمكن الطلبة من معرفة مستواه الدراسي ورتبه مقارنا ذلك بمستوى أقرانه ورتبهم. بواسطته يعبر الطلبة عن مدى استيعابهم لما تعلموه من خبرات ومعارف في مادة دراسية مقررة بطريقة علمية منظمة. يعتبر وسيلة يلجأ اليها المعلمين لمعرفة الفروق بين الطلبة ذلك من خلال مستوياتهم في التحصيل. يعمل التحصيل على كفاءة العملية التعليمية وذلك لتحقيق مستويات وأهداف ونواتج واضحة لصيالح الطلبة. وعليه فالهدف من التحصيل الدراسي هو الكشف عن قدرات وامكانيات الطلبة المختلفة في مختلف المواد الدراسية (علام، 2004،ص: 43). بعض مشاكل التحصيل الدراسي الجيد والحلول المقترحهة: - مات 1. بعض مشاكل التحصيل الدراسي يواجه المتعلم في مشواره الدراسي العديد من المشاكل التي تعرقل أو تعيق تحصيله الدراسي، سنحاول ذكر بعضها على النحو التالي: التساهل : سواء كان من طرف الوالدين \او المعلمين الذي يخلق رغبة متدنية لدى المتعلم في التحصيل الدراسي. الاهمال وعدم الاهتمام: كانشغال الاباء عن أبنائهم أو اهتمام المعلم ببعض المتعلمين واهماله للبقية يؤثر على تحصيلهم الدراسي. الرفض والنقد المستمرين: يتصف الأفراد الموصوفين أو الموصومين بالعجز أو الرفض وعدم
بتغير واحد أو أكثر من العناصر المتفاعلة المرتبطة بعلاقة ما. (ميلود، 2011، ص: 87).

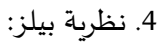
يرى بيلز في نظريته التفاعل الاجتماعي وحدد مراحله وأنماطه عامة في مواقف اجتماعية تجريبية وحدد بيلز في كتابه عملية التفاعل هذه وتلك الأنماط تحدث عند عملية التفاعل الاجتماعي على اساس نتائج دراساته وملاحظاته، والتفاعل الاجتماعي الذي درسه بيلز حول موضهوع أو مشكلة يريد اعضاء الجماعة الوصيول الى حلها، وللمشكلة عدة حلول وهناك عدة خطوات يمكن إتباعها للوصيول الى الحل وقدم بيلز نموذجاً لتحليل عملية التفاعل الاجتماعي احتل مركزاً هاماً في ديناميات الجماعة. التفاعل الاجتماعي في رأي بيلز هو طلب المعلومات والتعليمات والتكرارات والإِيضاح والتأكيد. (غيث، 1980، ص:118). اتحصيل الدراسي:

يشير مصطلح التحصيل الدراسي الى المستوى الاكاديمي الذي يحرزه الطالب في مادة دراسية معينة بعد تطبيق الاختبار عليه والهدف من الاختبار التحصيلي في هذه الحالة هو قياس مدى استيعاب الطالب للمعرفة والفهم والمهارات المتعلقة بالمادة الدراسية في أوقات معينة، ونقصيد بالمعرفة ما يملكه الطالب من معلومات والفهه يتضمن القدرة على التعبير عن المعرفة بطرق عديدة والمهارات هي معرفة عمل شيء (الصراف، 2003، ص:21). يوجد نوعان للتحصيل الدراسي (التحصيل الدراسي الجيد والتحصيل الدراسي الضعيف) فالتحصيل الدراسي الجيد هو استطاعة الشخص على سرعة تبويب معلوماته أي يحللها الى مختصر منظم يسهل عليه تذكره وهو الدافع القوي لدى الشخص لتنظيم أعماله والربط باستمرار بين المعلومات، فهو الكفاءة ذات الفعالية المقترنة بالسرعة والمثابرة والتحفظ وليس الابتكار أو التجديد، أما التحصيل الدراسي الضعيف هو 
انتهاج أساليب تدريس أثبتت نجاحتها وكفاءتها في

تنمية التحصيل.

خلق جو صفي يشجع على الإبداع والتعلم الجيد.

تطوير وتدريب التعليمي للمعلمين بما يناسب

الطرق الحديثة والتغيرات المستمرة في المناهج

والبرامج الدراسية. (عبدالهادي والعزة، 2004، ص صدئه

ص: 188-198). (198)

أنواع التحصيل الدراسي: (التي:

1. التحصيل الدراسي الجيد: يعرف باستطاعة لدراسي:

الشخص على سرعة تبويب معلوماته أي يحللها الى الى

مختصر منظم يسهل عليه تذكره وهو الدافع

القوي لدى الشخص لتنظيم أعماله والربط

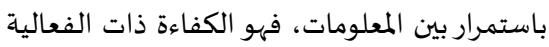

المقترنة بالسرعة والمثابرة والتحفظ وليس الابتكار

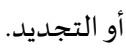

2. التحصيل الدراسي الضعيف: وهو التقصير

الملحوظ عن بلوغ مستوى معين من التحصيل

الذي تعمل المدرسة من أجله. (الدمنهوري

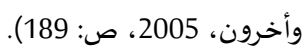

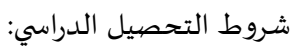

1. شروط التكرار: والمفيد منه هو القائم على

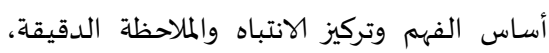

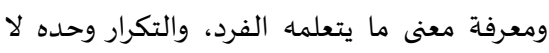
يكفي لعملية التعلم إذ لا بد ان يصاحسه الفرد، ولتكرار وحده توجيه

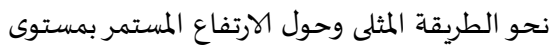
أوداء.

2. الدافع: وهو المحرك نحو النشاط المؤدي الى الى

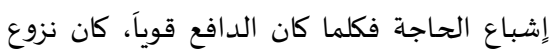
الفرد نحو النشاط المؤدي الى التعلم قوياً أيضاً،

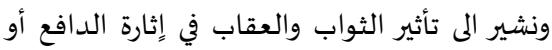
إِطفائه، فالتعزيز الايجابي يؤدي الى زيادة التعلم،

$$
\text { والتغير الايجابي في سلوك المتعلم. }
$$

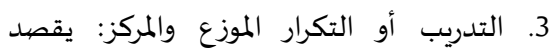

بالتدريب المركز ذلك التدريب الذي يتم في وقت واحد وفي دورة واحدة، أما التدريب الموزع فيتم في
اللباقة، بالإحساس بالنقص، والشراسة مما يؤثر على تحصيلهم الدراسي. عدم معرفة طرق الدراسة الصحيحة: ان عدم إلمام المتعلم بأهم الطرق والأساليب العلمية التي تمكنه من تفعيل طاقاته واستغلال قدراته العقلية، وكذلك عدم استغلال مكتبة المدرسة في تطوير قدراتهم المعرفية يؤثر سلباً على تحصيله الدراسي.

(عبد الهادي والعزة، 2004، ص ص: 188-193). المفاهيم الوالدية الخاطئة: ان قيام الوالدين صنادين بتعليم أبنائهم وتدريسهم وتربيتهم على التعلم في مرحلة مبكرة من الطفولة وقبل وصولهم الى مرحلة

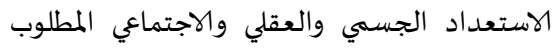
للتمدرس، يخلق في المراحل التعليمية اللاحقة مشاكل لدى المتعلم، وقد تؤثر سلباً على تحصيله الدراسي في المرحلة الثانوية على وجه الخصوص.

$$
\text { (نصر الله، 2004، ص: 90). }
$$

2. الحلول المقترحة لمشاكل التحصيل الدراسي: لقد شغل تدني التحصيل الدراسي العديد من الباحثين والدارسين في مختلف المجالات النفسية، الاجتماعية والاقتصادية، وسعت كلها الى ايجاد حلول التخفيف من انخفاض التحصيل، وقدموا العديد من البدائل والحلول ونذكر منها ما يلي: تشجيع الوالدين لأبنائهم على الدراسة وتعزيزهم والاهتمام بهم. تقبل المتعلمين وتشجيعهم على محاولة وبذل أقصى جهد من اجل النجاح وتفادي وتجنب مخلفات الإحباط والفشل.

تعريف التلاميذ بالتعليم الفعال واسلوب حل المشكلات وكيفية إِشباع رغباتهم وحب الاستطلاع. عدم الاسراف في التساهل مع المتعلمين ووضع قوانين وضوابط لسلوكهم. توعية الاولياء بالطرق السليمة للتعلم وكيفية

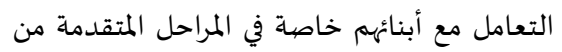

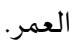


4. يعمل التحصيل على كفاءة العملية التعليمية وذلك لتحقيق مستويات وأهداف ونواتج واضحة لصالح التلميذ. ولهذا فالهدف من التحصيل الدراسي هو الكشف عن قدرات وامكانيات التلاميذ المختلفة في مختلف المواد الدراسية. (علام، 2004، ص: 43).

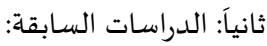
تعتبر الدراسات السابقة نقطة بداية لأي باحث حتى يستطيع ان يقارن ما وصل اليه في دراسته وبما وصل اليه ممن بحث قبله، فِإما أن يؤكد

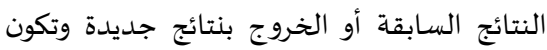
اضافة جديدة الى المعرفة الانسانية، ولهذا حاولنا الاطلاع على العديد من الدراسات المتشابهة والقرببة من موضوع دراستنا وكما يلي: دراسة شريف (2008) بعنوان (البيئة الاجتماعية المدرسية وعلاقتها بالمردود الدراسي) تهدف الباحثة من خلال دراستها توضيح علاقة

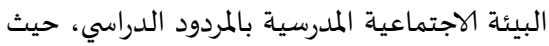
قامت الباحثة بدراسة استطلاعية على عينة بحجم (110) تلميذاً من تلاميذ المعيدين للسنة الثالثة ثانوي باحدى بلديات ولاية مسيلة، واستخدمت الباحثة المنهج الوصفي الارتباطي، وقد توصلت بلتئل الباحثة في الاخير الى النتائج التالية:

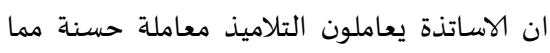

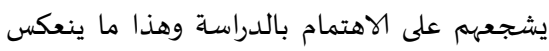
إيجاباً على نتائجهم الدراسية. ان تشجيع الاساتذة لتلاميذهم على الدراسة يدفعهم الى تحقيق نتائج دراسية أفضل. عدم شعور المبحوثين بالرضا عن الثانويات التي يدرسون بها مما يحبط عزيمتهم وهذا ما يؤثر سلباً

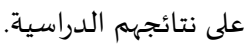
المماملة السيئة من طرف ادارة الثانوية كانت من لمن اخفاق التلاميذ في شهادة البكالوريا.

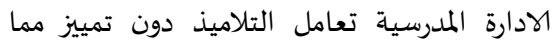
يشجعهم ويحفزهم على الدراسة.
فترات متباعدة تتخللها فترات من الراحة أو عدم

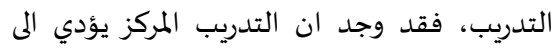
التعب والشعور بالملل، كما أن ما يتعلمه الفرد بالطريقة المركزة يكون عرضة للنسيان، وكذلك ان

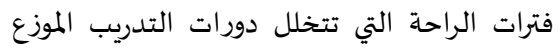

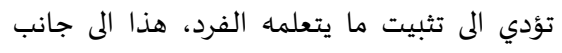
تجدد نشاط المتعلم بعد فترات الانقطاع، وإقباله على التعلم باهتمام كبير، وقد أثبتت الدراسات ان التدريب الموزع احسن من المتصل. (العيسوي، 2004، ص: 41). 4. الطريقة الكلية والجزئية: اختلف العلماء في تفضيل احدى الطريقتين على الاخرى ولكن من

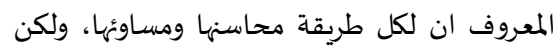
تفضل الطريقة الكلية اذا كانت غير مجزأة، أما

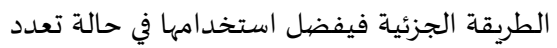
أجزاء المادة وصعوبتها. 5. نوع المادة ومدة تنظيمها: كلما كانت المادة مرتبة منطقياً ومترابطة الأجزاء واضحة المعنى سهل حفظها ومراجعتها. 6. التسميع الذاتي: وهو محاولة استرجاع المعلومات أثناء الحفظ مما يساعد على تثبيت المعلومات والقدرة على إِستدعائها. 7. التوجيه والارشاد: ثبت ان التدئل التحصيل الذي يقترن بالارشاد والتوجيه أفضل من التحصيل بدونهما حيث ان المحصل يستطيع ان يعي أهمية

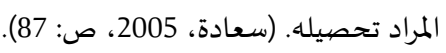

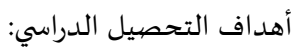
1. يمكن التلميذ من معرفة مستواه الدراسي ورتبه مقارناً ذلك بمستوى أقرانه ورتههم. 2. يعبر التلميذ بواسطته عن مدى استيعابهم لما تعلموه من خبرات ومعارف في مادة دراسية مقررة بطريقة علمية منظمة. 3. يعتبر وسيلة يلجأ اليها المعلمين لمعرفة الفروق ميطه التلاميذ ذلك من خلال مستوياتهم في التحصيل. 
تلميذاً، وتوصلت الباحثة الى أن هناك علاقة ارتباطية بين دلالة احصائية بين التفاعل الاجتماعي المدرسي والتحصيل الدراسي لدى تلاميذ السنة الثالثة ثانوي عند مستوى الدلالة 0.05 (علي، 2013، ص ص: ت - ث).

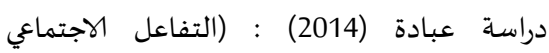
وعلاقته بالتحصيل الدراسي عند التلاميذ) هدفت الدراسة الى الكشف عن التفاعل الاجتماعي وعلاقته بالتحصيل الدراسي عند التلاميذ، تم إِتباع المنهج الوصفي التحليلي والذي يعد من أكثر

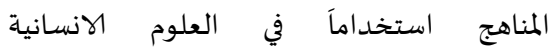
والاجتماعية، يتكون مجتمع الدراسة من تلاميذ رابعة متوسط، حجماه (163) تلميذاً وتم اختيار عينة قصدية حجمها (85) تلميذاً أي بنسبة 50\% من مجتمع الدراسة الأصلي، وخلصت الى النتائج

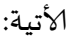

ان التعاون بين التلميذ وزملائه يساهم في التحصيل الدراسي عند تلاميذ المرحلة المتوسطة مما يشجع التلاميذ على التحضير لمستقبلهم الدراسي خاصة والاجتماعي عامة.

التكيف بين التلميذ وزملائه يساهم في التحصيل الدراسي عند تلاميذ المرحلة المتوسطة. التنافس بين التلميذ وزملائه يساهم في التحصيل الدراسي عند تلاميذ المرحلة المتوسطة. (عبادة، 2014، ص ص: أ-ب).

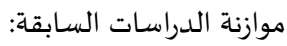
اتفقت الدراسة الحالية مع الدراسات السابقة في استعمال المقياس كأداة لجمع البيانات ولتحقيق أهدافها. تباينت الدراسات السابقة في عدد أفراد عينتها، فدراسة (شريف، 2008) قد بلغ عدد أفراد عينتها (110 تلميذا)، ودراسة (العقون، 2011) بلغت أفراد عينتها (100 تلميذ)، ودراسة (علي، 2013) بلغت 115 تلميذا، ودراسة (عبادة، 2014) قد بلغت 163 تلميذا، وهذا التباين يرجع الى ظروف
ان تعاون التلميذ مع جماعة رفاق المدرسية يدفعه الى احراز نتائج دراسية أحسن. (شريف، 2008، ص:أ-ب)

دراسة العقون (2011): البيئة الاجتماعية المدرسية وعلاقها بالتحصيل الدراسي) هدف البحث هو الكشف عن علاقة البيئة

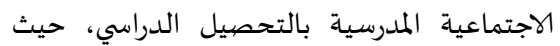
قام الباحث بدراسة ميدانية على عينة من تلاميذ

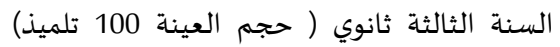
بثانويتي ابن رشيق القيرواني وثانوية المنقر الجديدة بولاية ورقلة، واستخدم الباحث في جمع البيانات (الاستبيان، المقابلة، السجلات والوثائق) وقد وصل

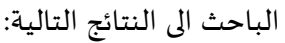
وجود علاقة إيجابية بين الاستاذ والتلميذ، وهذا من العوامل التي تساعد التلميذ للوصول الى إلى ليه تحصيل دراسي جيد. علاقة التلميذ بالادارة هي علاقة سلبية مما تؤثر على عملية التعليم وتساهم في تدني مستوى بلهي التحصيل الدراسي للتلميذ. وجود علاقة إرتباطية بين جماعة الرفاق لـاق والتحصيل الدراسي للتلميذ. وفي الهاية توصل الباحث الى ان البيئة الاجتماعية المدرسية تؤثر في عملية التحصيل الدراسي للتلميذ فكلما كانت البيئة إيجابية كان التأثير إيجابياً،

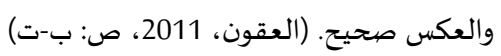

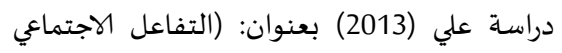

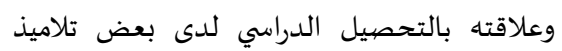
التعليم الثانوي) تهدف الدراسة الى معرفة العلاقة بين التفاعل

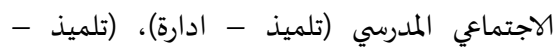

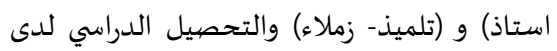
تلاميذ السنة الثالثة ثانوي، استخدم المنهاج الوصفي الارتباطي وتم تطبيق الدراسة ميدانياً على تلى تلانيد عينة من تلاميذ السنة الثالثة ثانوي (115) تلميذاً بنسبة 50\% من مجتمع البحث المقدر بـ (230) 
عبدالحفيظ وباهي، 2000، ص: 129)، وتتكون عينة هذا البحث من (147) طالب وطالبة بواقع (104) طالبة و (43) طالب من طلبة كلية التربية الأقسام العلمية جامعة كرميان، تم اختيارهم بطريقة عشوائية طبقية. أداة البحث: Research Tools بعد الاطلاع على الأدب التربوي والدراسات السابقة المتعلقة بموضوع المقياس (الاداة) مثل دراسة (شريف، 2008)، دراسة (العقوق، 2011)، دراسة (علي، 2013) ودراسة (عبادة، 2014) والاستفادة دراسة العةوف من اراء المحكمين، قام الباحث وبالاستفادة من

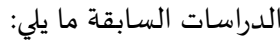
أولاً: بناء مقياس وفق الخطوات التالية: 1. تحديد السؤال الرئيسي والأسئلة الفرعية. 2. اعداد المقياس بالصورة الأولية حيث تبنيت مقياس (عبادة، 2014) وتضمنت (40) فقرة. 3. عرض المقياس على مجموعة من المحكمين التربويين ملحق رقم (3)، وقد تم الاخذ باراء المحكمين، حيث تم تعديل بعض الفقرات وازالة اخرى واضافة فقرات جديدة، واعادة صياغة لمعظم الفقرات، وقد أصبح عدد فقرات المقياس

بعد اجراء التعديلات (39) فقرة، ملحق (1)

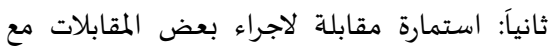
رؤوساء الأقسام وبعض الاساتذة الذين لهم علاقة بطلبة كلية التربية الأقسام العلمية بغية مساعدتنا

في توضيح الموضوع أكثر. ملحق رقم (2).

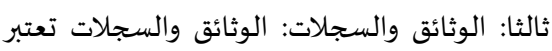

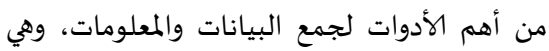

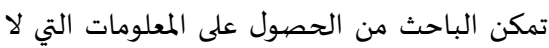
توافرها الأدوات الاخرى كالاستبيان والمقابلة.

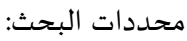
أقتصرت البحث الحالي على طلبة كلية التربية الأقسام العلمية (الكيمياء، الأحياء، الفيزياء والرياضيات) المراحل الرابعة جامعة كرميان للعام

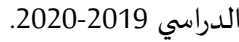

البحث التي أقتضتها كل دراسة. أما الدراسة الحالية فبلغت حجم عينتها (147) طالباً وطالبة. تباينت أماكن اجراء الدراسة، فقد اجريت كل من (شريف، 2008)، ( العقون، 2011)، (علي، 2013)

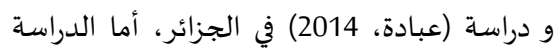
الحالية فقد اجريت في اقليم كوردستان العراق. الفصل الثالث: منهجية البحث: إن اختيار المنهج المستخدم للدراسة يعتبر أمراً تحدده طبيعة مشكلة البحث التي نريد دراستها، والغرض الاساسي من هذا البحث هو وصف واقعاً معين، والكشف عن علاقة التفاعل الاجتماعي (طالب- عناصر البيئة التعليمية) بالتحصيل الدراسي لطلبة كلية التربية جامعة كرميان، فالمنهج الأكثر ملائمة واستجابة لتطلعات الدراسة هو لدانه

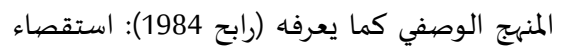
ينصب على ظاهرة اجتماعية أو نفسية كما هي موجودة في الواقع بعد تشخيصها وكشف جوانها وتحديد العلاقات بين عناصرها (رابح، 1984، ص:

استخدم الباحث المنهج الوصفي المستي في هذا البحث لأنه يناسب طبيعة المشكلة، حيث تم اعداد أداة البحث وتحكيمها حسب الأصول للتأكد من مدى مناسبتها لأهداف البحث ومحاولتها الاجابة على أسئلتها. مجتمع البحث: تكون مجتمع البحث من جميع

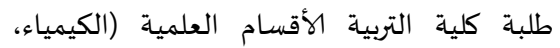
الفيزياء، الرياضيات والاحياء) جامعة كرميان للعام الدراسي 2019-2020 والبالغ عددهم (780) طالب وطالبة بواقع (482) طالبة و (298) طالباً. عينة البحث: الهدف من اختيار العينة هو

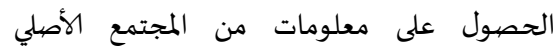
للبحث، والعينة هي إنتقاء عدد الأفراد لدراسة المعاد معينة تجعل النتائج منهم ممثلين لمجتمع الدراسة، فالاختيار الجديد للعينة يجعل النتائج قابلة

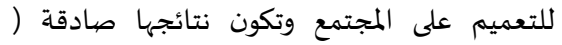


معامل ثبات جيد، وبذلك اتخذ المقياس شكله

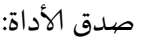

النهائي. ملحق رقم (1) مبات

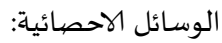

صدق الاختبار من الخصائص المهمة التي يجب

التأكد منها مصمم المقياس عندما يريد بناء مقياس

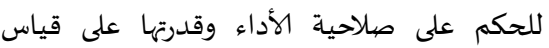

الظاهرة التي يراد دراستها ( عبدالرحمن، 1998،

ص:123)، ويعتبر من المؤشرات السايكومترية المهمة

(ابو زينة واخرون،2006 ،ص: 146)

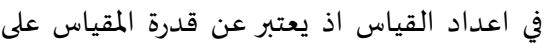

- النسبة المئوية=

وأخرون، 2006، ص: 50).

الفصل الرابع: عرض وتحليل وتفسير النتائج

أولاً: تحليل وتفسير البيانات العامة:

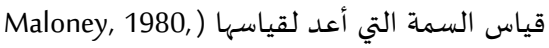

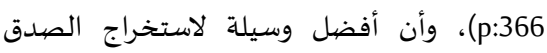
الظاهري هي تقدير عدد من الخبراء والمختصين

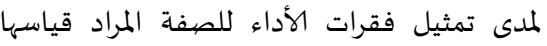
(عودة، 1998، ص: 37)، حيث تم عرض المقياس

تتسم عينة الدراسة بعدة خصائص في ضوء بعض لبول من قبل الباحث على مجموعة من الخبراء متغيرات البحث يمكن توضيحها في الجداول أدناه:

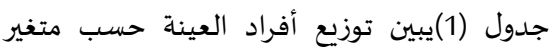
والمختصين في مجال التربية وعلم النفس وطرائق التدريس، وقد أعتمدت الفقرة التي حصلت على نسبة (80\%) فأكثر وهي نسبة الاتفاق التي تم تحديدها محكماً لصلاحية الفقرة واهمال الفقرة التي دون ذلك، حيث أشار بلوم واخرون (Bloom (and et al (75\%) فأكثر بين المحكمين، يمكن عدها فقرة صالحة لتحقيق صدق لها (بلوم واخرون، 1983، ص: 126) (126)

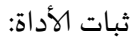

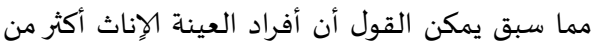

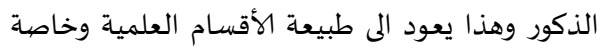

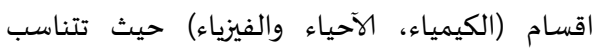
طبيعة وعمل ورغبات (الإناث) الطالبات أكثر من رغبات (الذكور) الطلاب مع هذه الأقسام. جدول (2) يبين توزيع أفراد العينة حسب متغير القسم

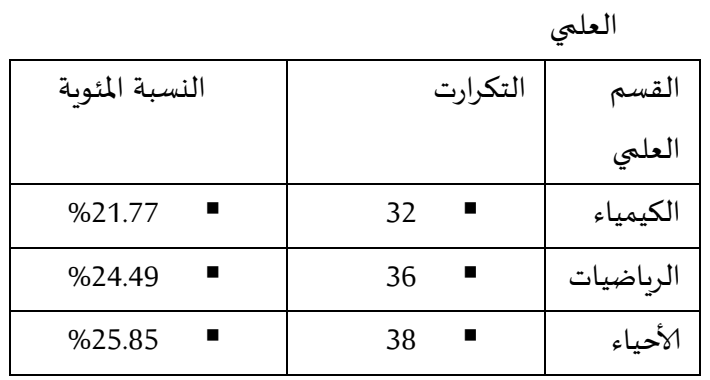

نقصد بالثبات الحصول على نفس النتائج تقريباً

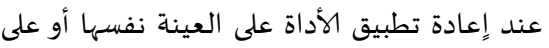
عينة اخرى مكافئة (أبو جلالة، 1999، ص:108).

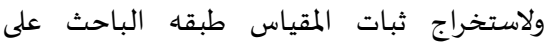
مجموعة من المبحوثين بلغ عددهم (20) مبحوثاً، اختيروا بطريقة عشوائية ومن غير العيدة لمدينة الاساسية، وبعد مضي اسبوعين تم تطبيقها على العينة نفسها وتعد مدة اسبوعين مدة ملائمة

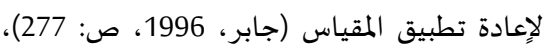
وبعد تحليل فقرات المقياس باستعمال معامل ارتباط بيرسون، وجد انه يساوي (0.78) وهو 
يوضح الجدول رقم (4) والذي يبين توزيع أفراد العينة

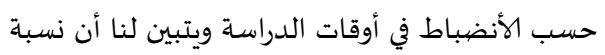
88.44 منهم أكدوا الانضباط في مراجعة المحاضرات والدروس، بينما نفى 11.56\% الانضباط في أوقات الدراسة، حيث يتبين لنا من هذه النتائج أن غالبية

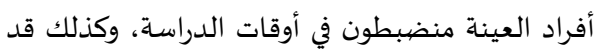
يؤثر على مدى إِستيعابهم للدروس والمحاضرات وهذا يعود الى الحضور الدائم والمستمر والالتزام بالوقت مداهي

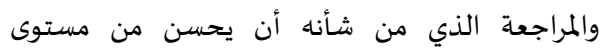
تحصيلهم الدراسي، وهذا ما أكده رؤساء الأقسام والاساتذة أثناء المقابلة. جدول (5) يبين توزيع أفراد العينة حسب نمط المراجعة الذي يتبعه الطلبة بالنسبة للمعيدين والغير

\begin{tabular}{|c|c|c|c|c|c|c|}
\hline & & & \multicolumn{4}{|c|}{ معيدين } \\
\hline النسبة & المجهم & النسبة & غير & النسبة & معي & نمط \\
\hline المئوية & وع & المئوية & معيد & المئوية & د & المرا \\
\hline 77. & 1 & 67. & 9 & 10. & 1 & وحد \\
\hline 55 & 1 & 35 & 9 & 20 & 5 & ك \\
\hline$\%$ & 4 & $\%$ & & $\%$ & & \\
\hline 22. & 3 & 21. & 3 & 0,6 & 1 & مع \\
\hline 45 & 3 & 77 & 2 & $\% 8$ & & الزه \\
\hline$\%$ & & $\%$ & & & & لاء \\
\hline 10 & 1 & 89. & 1 & 10. & 1 & المجج \\
\hline$\% 0$ & 4 & 12 & 3 & 88 & 6 & موع \\
\hline & 7 & $\%$ & 1 & $\%$ & & \\
\hline
\end{tabular}

استناداً الى معطيات الجدول رقم (5) أعلاه والذي لتولي

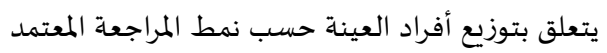
لدى طلبة كلية التربية الأقسام العلمية المعيدين والغير المراد المبند معيدين نجد أن 10.20\% منهم يعتمدون نمط المراجعة

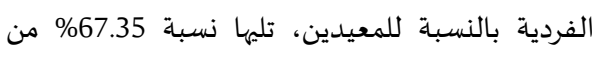
أفراد العينة الغير معيدين يعتمدون المراجعة الفردية،

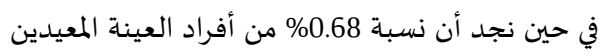

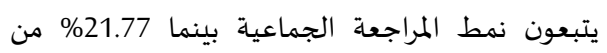

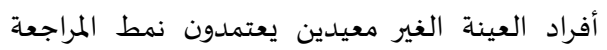

\begin{tabular}{|c|c|c|c|c|}
\hline & & & & (بايولوجي) \\
\hline \%27.89 & - & 41 & - & الفيزياء \\
\hline$\% 100$ & - & 147 & - & المجموع \\
\hline
\end{tabular}

معطيات الجدول رقم (2) توضح لنا توزيع أفراد العينة

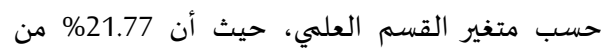

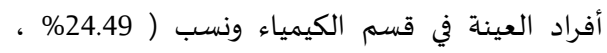

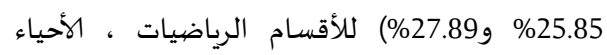
والفيزياء على التوالي، ومن خلال هذه النسب يتبين لنا ان توزيع أفراد العينة لهذه الأقسام متقاربة تقريباً، وذلك لتشابه طبيعة و عملهذه الأقسام تقريباً.

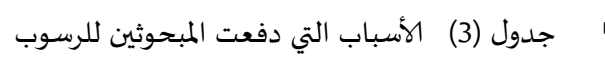

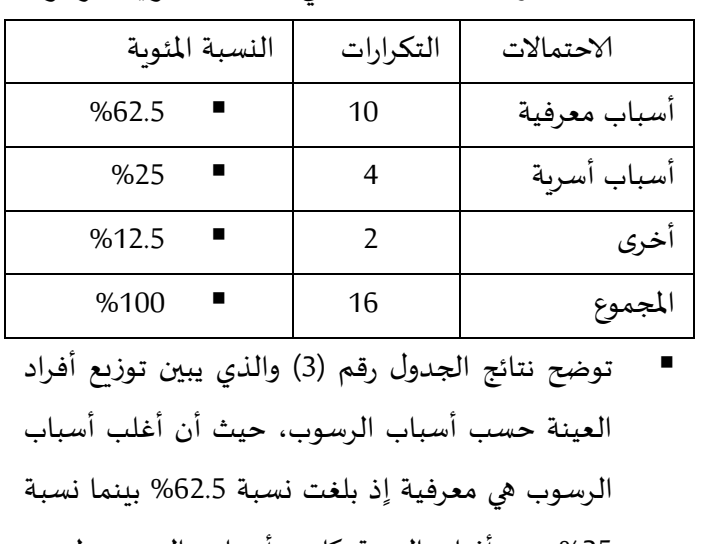
25 من أفراد العينة كانت أسباب الرسوب لديهم

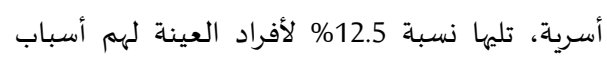
أخرى دفعتهم للرسوب. ثانياً: تحليل وتفسير فرضيات الدراسة: بعد الدراسة الميدانية وعرض محتوى الجداول الاحصائية حسب ما جاء في كل محور وتحليل وتفسير البيانات، فيما يلي عرض النتائج:

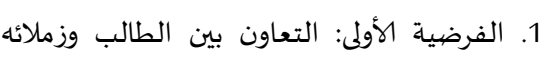
يساهم في التحصيل الدراسي عند طلبة المرحلة

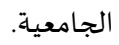
جدول (4) يبين توزيع أفراد العينة حسب مدى الجائ الانضباط في أوقات الدراسة

\begin{tabular}{|c|c|c|c|}
\hline \multicolumn{2}{|c|}{ النسبة المئوية } & التكرار & الاجابة \\
\hline \%88.44 & - & 130 & نعم \\
\hline$\% 11.56$ & - & 17 & كلا \\
\hline$\% 100$ & - & 147 & المجموع \\
\hline
\end{tabular}


التمارين الصعبة بنسبة 23.13\%، بينما نسبة المساعدة

على فهم الدروس 17.69\% في حين أن نسبة المسـاعدة على المذاكرة والحفظ 19.04\%، و تليها نسبة 40.14\%

$$
\text { من المبحوثين يعارضون ذلك. }
$$

جدول (8) يبين توزيع أفراد العينة حسب مدى تبادل

$$
\text { المراجع فيما بينهم التي تساعد على الدراسـة }
$$

\begin{tabular}{|c|c|c|c|c|}
\hline \multicolumn{2}{|c|}{ لنسبة المئوية } & \multicolumn{2}{|c|}{ التكرارات } & اجابة \\
\hline$\% 53.74$ & - & 79 & - & نعم \\
\hline \%46.26 & - & 68 & - & كلا \\
\hline$\% 100$ & - & 147 & - & المجموع \\
\hline
\end{tabular}

تكشف معطيات الجدول أعلاه والذي يتعلق بتوزيع أفراد العينة حسب تبادل الطلبة المراجع فيما بينهم التي تساعد على التحصيل الدراسي، أن نسبة الذين يتبادلون المراجع فيما بينهم بلغت 53.74\% بينما أكدت نسبة 46.26\% عدم تبادل المراجع التي تساعد على

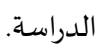

\begin{tabular}{|c|c|c|c|c|}
\hline \multicolumn{2}{|c|}{ النسبة المئيةية } & التكرارات & \multicolumn{2}{|l|}{ الاحتمالات } \\
\hline$\% 27.21$ & - & 40 & الاستاذ & نعم \\
\hline \%4.08 & - & 6 & بالزملاء & \\
\hline$\% 24.49$ & - & 36 & بالمنهج العلمي & \\
\hline \%55.78 & - & 82 & المجموع & \\
\hline$\% 44.22$ & - & 65 & كاك & \\
\hline \%100 & - & 147 & & المحح. \\
\hline
\end{tabular}

جدول (9) يبين توزيع أفراد العينة حسب مدى وجود

مشاكل تتعلق بالدراسة ونوع هذه المشاكل

يبيلن الجدول رقم (9) أعلاه والذي يتعلق بتوزيع أفراد اللينة حسب وجود مشاكل تتعلق بالدراسـة حيث نجد أيل 55.78\% منهم يعانون من مشاكل تتعلق بالدراسة حليث أكد المبحوثين وجود مشاكل تتعلق بالأستاذ بنسبة 27.21\%، و 4.08\% مع زملائهم بينما بلغت نسبة 24.49\% من الذين يعانون مشاكل تتعلق بالمنهج العلمي، تليها نسبة 44.22\% من العينة أكدوا عدم

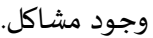
-
الجماعية.نلاحظ من خلال نتائج الجدول أعلاه أن أغلب الطلبة المبحوثين يعتمدون على المراجعة الفردية للمعيدين والغير معيدين، وهذا يعود الى طبيعة العلاقة الاجتماعية بينهم وهذا ما أكده رؤساء الأقسام والاساتذة أثناء المقابلة.

\begin{tabular}{|c|c|c|c|c|c|}
\hline & & \multicolumn{4}{|c|}{ بعضهم } \\
\hline \multicolumn{2}{|c|}{ النسبـة المئويـة } & \multicolumn{2}{|c|}{ التكرارات } & \multicolumn{2}{|c|}{ الاجابة } \\
\hline$\% 61.22$ & - & 90 & - & نعم & - \\
\hline \%38.78 & - & 57 & - & كلا & - \\
\hline$\% 100$ & - & 147 & - & & المجموع \\
\hline
\end{tabular}
جدول (6) يبين توزيع أفراد العينة حسب مدى مناقشة المواضيع والدروس التي يفهمها الطلبة مع

من خلال معطيات الجدول أعلاه والذي يكشف مدى مناقشة المواضيع والدروس التي يفهمها الطلبة مع بعضهم البعض، حيث قدرت نسبة الذين يناقشون المواضيع والدروس العلمية 61.22\% تليها نسبة 38.78 تمثل أفراد العينة الذين لا يناقشون المواضيع العلمية. إذ أن أغلب المبحوثين يحرصهون على الدراسة والمراجعة وهذا ما يؤدي الى تبسيط المصطلحات الصعبة لديهم ودافعية الطلبة للنجاح. جدول (7) يبين توزيع أفراد العينة حسب مدى

\begin{tabular}{|c|c|c|}
\hline النسبة المئوية & التكرار & العينة \\
\hline 23.13 & 34 & يساعد على \\
\hline
\end{tabular}
مساعدة بعضهم البعض في أداء الواجبات العلمية

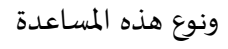

\begin{tabular}{|c|c|c|c|c|}
\hline \%17.69 & - & 26 & - & فهم الدروس \\
\hline \%19.04 & - & 28 & - & المذاكرة والحفظ \\
\hline$\% 59.86$ & - & 88 & - & المجموع \\
\hline$\% 40.14$ & - & 59 & - & كلا \\
\hline$\% 100$ & - & 147 & " & المجموع \\
\hline
\end{tabular}

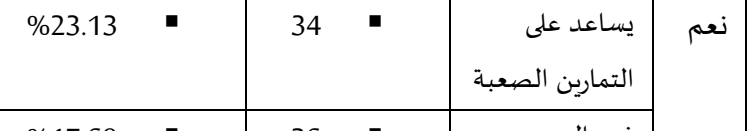

من خلال الجدول أعلاه (7) والذي يتعلق بتوزيع أفراد العينة حسب مدى مساعدة بعضهم البعض في أداء الواجبات العلمية ونوع المساعدة نجد أن نسبة المساعدة بينهم في أداء الواجبات هي 59.86\%، منها حل 
يساهم في التحصيل الدراسي في المرحلة الجامعية

قد تحققت في معظمها.

2. الفرضية الثانية: التكيف بين الطالب وزملائه

يساهم في التحصيل الدراسي لدى الطلبة

جدول (11) يبين توزيع أفراد العينة حسب علاقة ليحيل

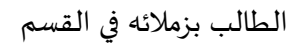

\begin{tabular}{|c|c|c|c|c|}
\hline المئوية & - & ات اتكرار & - & " ل \\
\hline$\% 54.42$ & - & 80 & - & جيدة \\
\hline \%40.82 & - & 60 & - & حسنة \\
\hline$\% 4.76$ & - & 7 & - & مضطربة \\
\hline \%100 & - & 147 & - & المجموع \\
\hline
\end{tabular}

من خلال الجدول أعلاه والذي يوضح طبيعة علاقة الطالب مع زملائه، حيث أكد معظم أفراد العينة بأن علاقهمم ببعضههم جيدة وقدر نسبتهم بـ 54.42، تلهيا نسبة الطلبة الذين أكدوا بأن علاقتهم حسنة مع بعضهه بـ 40.82\% في حين أن

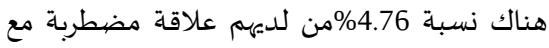
زملايهم. ويتضح من خلال ما سبق أن أغلب أفراد العينة لدههم علاقات جيدة مع زملاههم وتعتبر هذه العلاقات مهمة في المحيط الدراسي ويشعر فهيا الطالب بكيانه وأهميته ووضعاه الاجتماعي كما تنمي لديه الثقة بالنفس. جدول (12) يبين توزيع أفراد العينة حسب مدى بلى

\begin{tabular}{|c|c|c|c|c|}
\hline & \multicolumn{4}{|c|}{ اهتماهههم بنجاح زملائهم } \\
\hline المئوية & - & التكرارات & - & بالة \\
\hline$\% 88.44$ & - & 130 & - & نعم \\
\hline \%11.56 & - & 17 & - & كلا \\
\hline$\% 100$ & - & 147 & - & 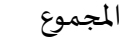 \\
\hline
\end{tabular}

يبين الجدول رقم (12) توزيع أفراد العينة حسب مدى اهتمام الطالب بنجاح زملائه حيث أن نسبة 88.44 من أفراد العينة مهتمون بنجاح زملائهم بينما 11.56\% لا ههمهم نجاح زملايهم.
جدول (10) يبين توزيع أفراد العينة حسب مدى التعاون في حل مشاكلهم

\begin{tabular}{|c|c|c|c|c|c|}
\hline \multirow{2}{*}{\multicolumn{2}{|c|}{ النسبة المئوية }} & \multicolumn{2}{|c|}{ التكرارات } & \multicolumn{2}{|c|}{ اجابة العينة } \\
\hline & & 10 & - & نعم & - \\
\hline$\% 31.3$ & - & 46 & - & كلا & - \\
\hline$\% 100$ & - & 147 & - & & المجموع \\
\hline
\end{tabular}

من خلال الجدول رقم (10) أعلاه والذي يتعلق بتوزيع أفراد العينة حسب تعاون الطلبة في حل الجدال مشاكلهم نجد أن نسبة 68.7\% منهم يستعينون

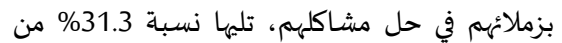

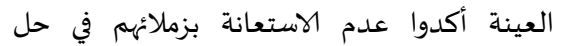
مشاكلهم، وهذا ما أكدوا بعض الاساتذة ورؤساء الأقسام في استمارة المقابلة. النتائج العامة للفرضية الأولى: استناداً الى المعلومات والبيانات الواردة في الجداول من (10-4) أتضح لنا أن هناك (88.44\%) منضبطون في أوقات الدراسة حيث أن الإعداد المبكر والالتزام بالوقت والمراجعة للدراسة يسهل

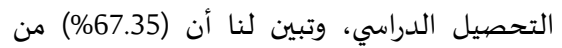
أفراد العينة الغير معيدين يعتمدون نمط المراجعة الدراسئ الفردية، اذ ان الطلبة يحاولون الحصول على نفس لفس الهدف وهو النتائج الجيدة رغم اختلاف نمط المرجعية، وتبين أيضاً أن (61.22\%) يناقشون المواضيع والدروس العلمية داخل القسم، وقد مثلت نسبة (59.86\%) مساعدة الطلبة بعضهم البعض في أداء الواجبات العلمية، ومثلت نسبة (53.74\%) تبادل المراجع والمصادر التي تساعد على الدراسة بين الطلبة حيث يساهم هذا في رفع مستوى التحصيل الدراسي للطلبة، ومثلت نسبة (55.78\%) وجود مشاكل دراسية سواء كان مع النعيل

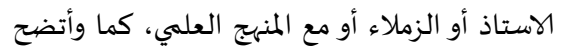
أن نسبة (68.7\%) من العينة متعاونون فيما بينهم

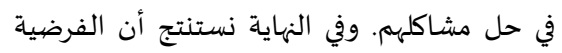
الجزئية الأولى المتعلقةبالتعاون بين الطالب وزملائه 
جدول (15) توزيع يبين توزيع أفراد العينة حسب

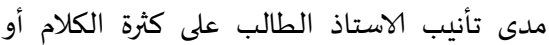

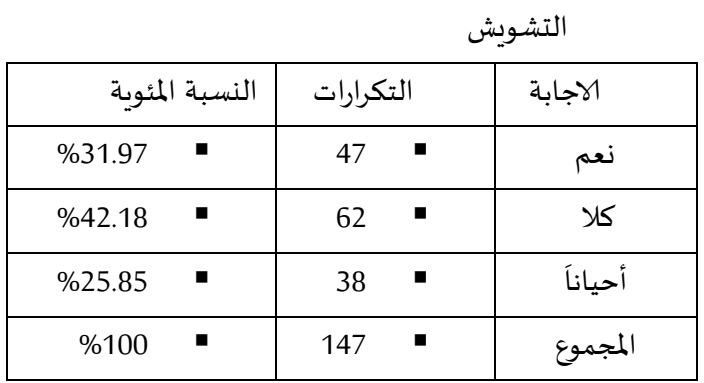

من خلال الجدول رقم (15) يتضح ان نسبة 31.97 من التلاميذ أجابوا بـ (نعم) أي ان الاستاذ قام بتأنهه على على الكلام أو كثرة التشويش، في

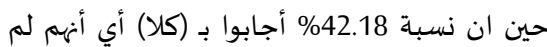

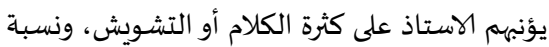

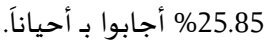
جدول (16) يبين توزيع أفراد العينة حسب مدى الدي أهمية مبدأ المساواة في تحفيز الطلبة لبذل جهد

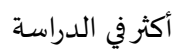

\begin{tabular}{|c|c|c|c|c|c|}
\hline \multicolumn{2}{|c|}{ النسبة المئوية } & \multicolumn{2}{|c|}{ التكرارات } & \multicolumn{2}{|c|}{ الاجابة } \\
\hline$\% 82.99$ & - & 122 & - & نعم & - \\
\hline \%17.01 & - & 25 & - & كلا & - \\
\hline$\% 100$ & - & 147 & - & & \\
\hline
\end{tabular}

استناداً الى الجدول أعلاه يتبين لنا أن نسبة 82.99 من الطلبة أجابوا بـ (نعم) أي أن لمبدأ

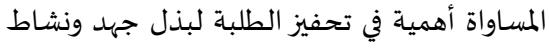
أكثر في الدراسة، في حين أن نسبة 17.01\% من الطلبة أجابوا بـ كلا أي أن مبدأ المساواة ليس له له

$$
\text { أهمية في تحفيز الطلبة. }
$$

جدول (17) يبين توزيع أفراد العينة حسب مدى تهمير حرص الاستاذ على توفير جو تعليي يساعد على

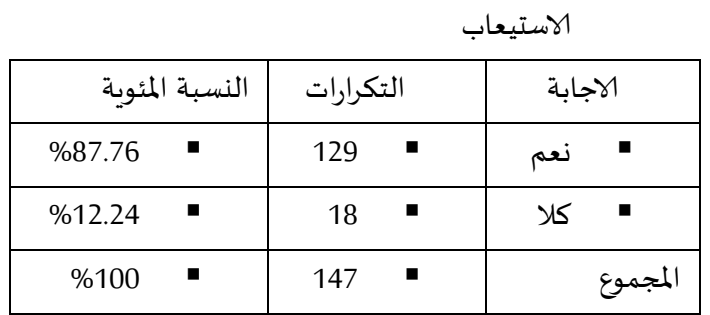

جدول (13) يبين توزيع أفراد العينة حسب مدى

\begin{tabular}{|c|c|c|c|c|}
\hline المئوية & - & التكرارات & " & الاجابة \\
\hline$\% 47.62$ & - & 70 & - & نعم \\
\hline \%32.65 & - & 48 & - & كلا \\
\hline \%19.73 & - & 29 & - & أحياناً \\
\hline \%100 & - & 147 & - & المجموع \\
\hline
\end{tabular}
تأكد الاستاذ من فهم الطالب للدرس لترس

يكشف الجدول أعلاه والذي يتعلق بتوزيع أفراد العينة حسب مدى تأكد الاستاذ من فهم الطلبة للمحاضرات والدروس، حيث كانت نسبة الذين

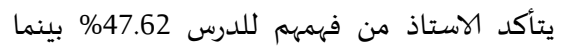

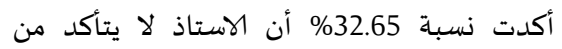
فهمهم الدرس في حين أن 19.73\% أكدوا أن احياناً ما يتأكدوا الاستاذ من فهمهم الدرس.

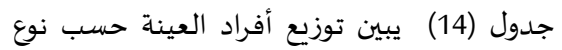

\begin{tabular}{|c|c|c|c|c|}
\hline & & \multicolumn{3}{|c|}{ الطالب } \\
\hline \multicolumn{2}{|c|}{ النسبة المئوية } & \multicolumn{2}{|c|}{ التكرارات } & الاجابة \\
\hline \%18.37 & - & 27 & - & ألعاب \\
\hline \%81.63 & - & 120 & - & $\begin{aligned} \text { إِحياء } \\
\text { المناسبات }\end{aligned}$ \\
\hline$\% 100$ & - & 147 & - & المجموع \\
\hline
\end{tabular}
النشاطات الرياضية والثقافية التي يشارك فهيا

يبين الجدول رقم (14) والذي يتعلق بتوزيع أفراد العينة حسب نوع النشاطات التي يشارك فيها الطالب، حيث كانت نسبة الذين يشاركون في

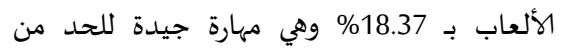
الضغوط ولخفض مستوى القلق وزيادة قدرات الجسم، بينما نسبة إِحياء المناسبات بلغت \%1.63 وتعد هذه المناسبات ظاهرة اجتماعية تؤثر وتتأثر بغيرها، فممارسة النشاطات بشكل إِيجابي، له تأثير على الفرد من النواحي الاجتماعية

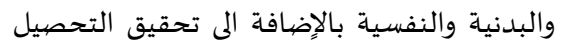

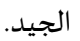




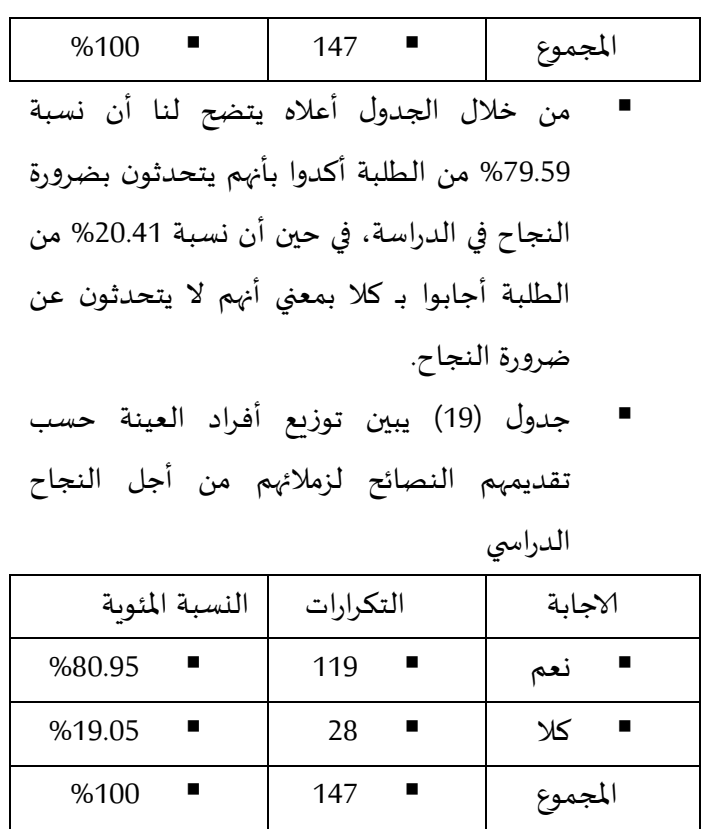

من خلال البيانات أعلاه في الجدول رقم (19) والمتعلقة بتوزيع أفراد العينة حسب تقديم الطالب البات التبات النصائح لزملائه من أجل النجاح وبلغت نسبتهم بـ بـ المادئ 80.95 في حين نسبة الطلبة التي لا يقدمون النصائح لزملايهم بلغت 19.05\%، ويدل هذا بلا شك أن أغلبية الطلبة يبدون أهتمامهم بنجاح زملايهم مما يؤدي الى زيادة التنافس بينهم، ويدعم التبه الروابط والعلاقات بينهم ويزيد من الثقة بأنفسهم

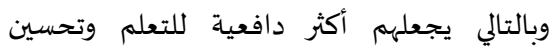

$$
\text { تحصيلهم الدراسي. }
$$

جدول (20) يبين توزيع أفراد العينة حسب نمو

روح المنافسة نتيجة النصائح اللازمة بين الطلبة

\begin{tabular}{|c|c|c|c|c|c|}
\hline \multicolumn{2}{|c|}{ النسبة المئوية } & \multicolumn{2}{|c|}{ التكرارات } & \multicolumn{2}{|c|}{ الاجابة } \\
\hline \%82.31 & - & 121 & - & نعم & - \\
\hline \%17.69 & - & 26 & - & كلا & - \\
\hline$\% 100$ & - & 147 & - & ميموع & \\
\hline
\end{tabular}

يبين الجدول رقم (20) والخاص بتوزيع أفراد العينة حسب نمو روح المنافسة نتيجة النصائح اللازمة بين الطلبة يتضح لنا أن نسبة 82.31\% من العند الطلبة أجابوا بكلمة نعم ونسبة الطلبة الذين أجابوا بكلمة كلا بلغت 17.69\% وهذا يعني أن نمو
من خلال الجدول رقم (17) أعلاه والمتعلقة بتوزيع أفراد العينة حسب مدى حرص الاستاذ على توفير

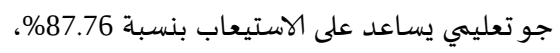
تلهيا نسبة 12.24\% من الطلبة الذين أكدوا عدم حرص الاستاذ على توفير جو يساعد على الاستيعاب. النتائج العامة للفرضية الثانية: من خلال المعلومات الواردة في الجداول من (1117) نستنتج بأن نسبة (54.42\%) من أفراد العينة

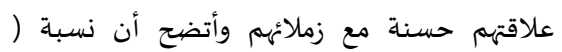
88.44\%) من العينة يهتمون بنجاح زملايهم وهذا

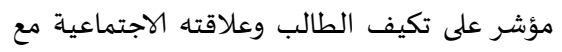
الاخرين، وأن العلاقة بينه وبين زملائه وثيقة الصلة يتفاعل معهم ويتحمل المسؤولية الاجتماعية، كما

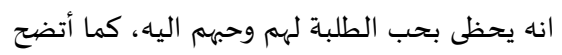
لنا أن نسبة ( 47.62\%) من الطلبة يتأكد الاستاذ

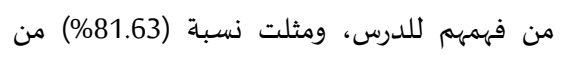

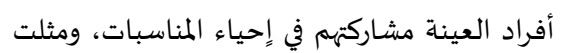
نسبة (31.97) من أفراد العينة قام الاستاذ بتأنههم

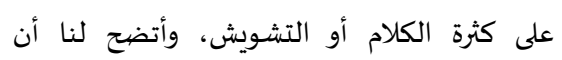
(82.99\%) أن لمبدأ المساواة أهمية في تحفيز الطلبة الندان

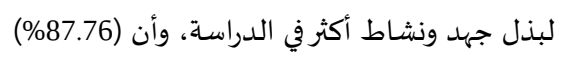
يحرص الاستاذ على توفير جو تعليي يساعدهم

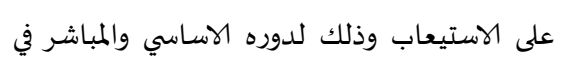

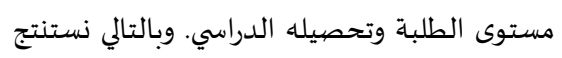
أن الفرضية الجزئية الثانية المتعلقة بالتكيف بين

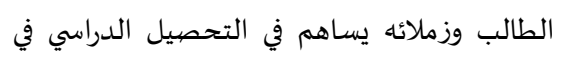
المرحلة الجامعية قد تحققت في معظمها. 3. الفرضية الثالثة:التنافس بين الطالب (الطالبة) وزملائه يساهم في التحصيل الدراسي لدى الطلبة.

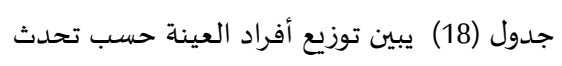
الطالب مع زملائه بضرورة النجاح في الكلية

\begin{tabular}{|c|c|c|c|c|c|}
\hline \multicolumn{2}{|c|}{ النسبة المئوية } & \multicolumn{2}{|c|}{ التكرارات } & \multicolumn{2}{|c|}{ الاجابة } \\
\hline$\% 79.5 \mathrm{~s}$ & - & 117 & - & קe & \\
\hline$\% 20.41$ & - & 30 & - & كلا & \\
\hline
\end{tabular}




\begin{tabular}{|rl|rl|r|}
\hline$\% 60.54$ & - & 89 & - & كعم \\
\hline$\% 39.46$ & - & 58 & - & - \\
\hline$\%$ & 147 & - & - \\
\hline
\end{tabular}

من خلال الجدول رقم (23) والخاص بتوزيع أفراد العينة حسب دور الاستاذ في خلق روح التحدي بين الجدان

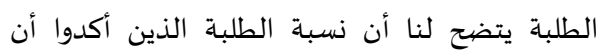
للاستاذ دور مهم في خلق روح التحدي بين الطلبة بلغت 60.54 والذين أجابوا عكس ذلك رول بلغت نسبة

\%39.46

جدول (24) يبين أراء أفراد العينة حول التنافس

بينهم كجماعة الرفاق وعلاقته بالمستوى التعليمي

\begin{tabular}{|c|c|c|c|c|c|}
\hline \multicolumn{2}{|c|}{ النسبة المئوية } & \multicolumn{2}{|c|}{ التكرارات } & \multicolumn{2}{|c|}{ الاجابة } \\
\hline$\% 80.27$ & - & 118 & - & نعم & - \\
\hline \%19.73 & - & 29 & - & كلا & - \\
\hline$\% 100$ & - & 147 & - & & \\
\hline
\end{tabular}

استناداً الى الجدول رقم (24) أعلاه والخاص بتوزيع

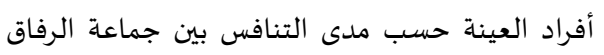

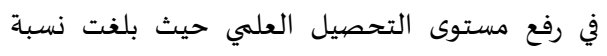

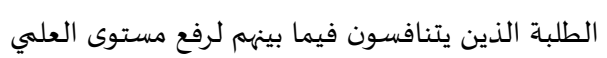
بلغت 80.27\% بينما نسبة الذين لا يتنافسون بلغت

\%19.73

جدول (25) يبين توزيع أفراد العينة حسب شكر

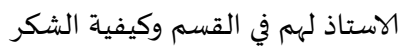

\begin{tabular}{|c|c|c|c|c|c|}
\hline \multicolumn{2}{|c|}{ النسبة المئوية } & \multicolumn{2}{|c|}{ التكرارات } & \multicolumn{2}{|c|}{ الاحتمالات } \\
\hline$\% 2.04$ & - & 3 & - & مادي & \\
\hline \%88.44 & - & 130 & - & لفظي & نعم \\
\hline$\% 90.48$ & - & 133 & " & المجمموع & \\
\hline \%9.52 & - & 14 & - & كلا & - \\
\hline$\% 100$ & - & 147 & - & & المجمو \\
\hline
\end{tabular}

يبين الجدول رقم (25) والخاص بتوزيع أفراد العينة حسب شكر الاستاذ لهم في القسم وكيفية الشكر، بلغت نسبة الاجابة بنعم 90.48\% أي أن الاستاذ يقوم بشكرهم في القسم، حيث أن 2.04\% من هذه النسبة يشكرهم الاستاذ شكر مادي، تلهيا نسبة 88.44\% من من هن ان
روح المنافسة نتيجة النصائح اللازمة بين الطلبة ليس لها أهمية.

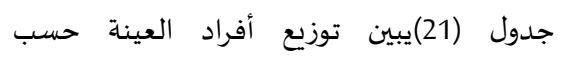

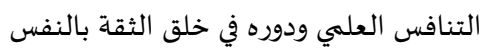

\begin{tabular}{|c|c|c|c|c|c|}
\hline \multicolumn{2}{|c|}{ النسبة المئوية } & \multicolumn{2}{|c|}{ التكرارات } & \multicolumn{2}{|c|}{ الاجابة } \\
\hline$\% 89.12$ & - & 131 & - & نعم & - \\
\hline \%10.88 & " & 16 & - & كلا & - \\
\hline$\% 100$ & - & 147 & - & & \\
\hline
\end{tabular}

من خلال الجدول رقم (21) والذي يتعلق

بالتنافس العلمي ودوره في خلق الثقة بالنفس،

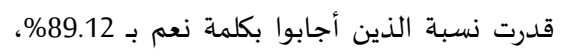

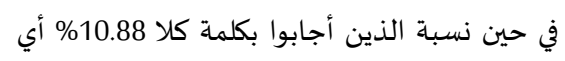
بمعنى ليس لديهم إِهتمام بالتنافس العلمي الذي لئل يخلق الثقة بالنفس. جدول (22) يوضح توزيع أفراد العينة حسب بلفي قيامهم بتمارين جماعية لبعث روح التنافس

\begin{tabular}{|c|c|c|c|c|c|}
\hline \multicolumn{2}{|c|}{ النسبة المئوية } & \multicolumn{2}{|c|}{ التكرارات } & \multicolumn{2}{|c|}{ الاجابة } \\
\hline$\% 55.1$ & - & 81 & - & نعم & - \\
\hline$\% 44.9$ & - & 66 & - & كلا & - \\
\hline$\% 100$ & - & 147 & - & & المجموع \\
\hline
\end{tabular}

يبين الجدول رقم (22) أن نسبة الطلبة الذين

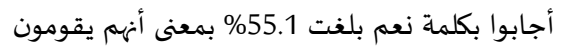
بتمارين جماعية لبعث روح التنافس لديهم، بينما

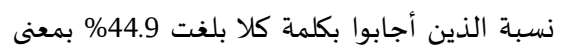

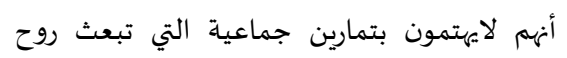
المنافسة، ومما سبق نلاحظ أن أغلب الطلبة المبحوثين أكدوا قيامهم بتمارين جماعية لبعث روح التنافس، وتتفاعل مجموعة كبيرة من الطلبة

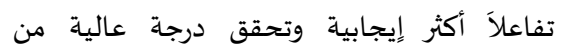
التنافس وتحسين تحصيلهم الدراسي، بينما الطلبة الذين لا يكون لديهم تنافس فيما بينهم هم الذين لا يهتمون بتمارين جماعية. جدول (23) يبين توزيع أفراد العينة حسب دور الاستاذ في خلق روح التحدي بين الطلبة الاجابة 
استناداً الدعطيات الجدول أعلاه والخاص بتوزيع أفراد العينة حسب مدى تشتت تفكيرهم نتيجة الضوضاء والشغب داخل القسم، تبين لنا أن نسبة

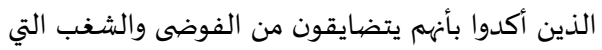
تشتت تفكيرهم داخل القسم بلغت 88.44\%، في حين أن نسبة الذين أكدوا أن ليس لديهم أي مشكلة في

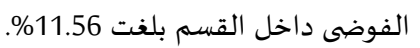
جدول (29) يبين توزيع أفراد العينة حسب تأثرهم من حصول زملائهم على درجات أعلى منهم

\begin{tabular}{|c|c|c|c|c|}
\hline \multicolumn{2}{|c|}{ النسبة المئوية } & \multicolumn{2}{|c|}{ التكرارات } & الاجابة \\
\hline \%82.99 & - & 122 & - & نعم \\
\hline$\% 17.01$ & - & 25 & - & كلا \\
\hline \%100 & - & 147 & - & المجموع \\
\hline
\end{tabular}

استناداً الى الجدول أعلاه تبين لنا أن نسبة الطلبة الذين أكدوا أنهم يتضايقون من حصول زملائهم على درجات أعلى منهم بلغت 82.99\%، بينما نسبة

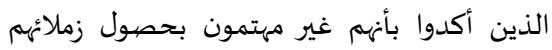

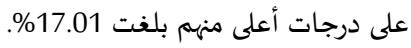

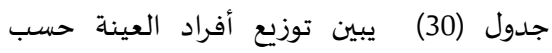
تفضيل الاستاذ بعض الطلبة على البعض داخل

\begin{tabular}{|c|c|c|c|c|c|}
\hline & & \\
\hline \multicolumn{2}{|c|}{ النسبة المئوية } & \multicolumn{2}{|c|}{ التكرارات } & \multicolumn{2}{|c|}{ الاجابة } \\
\hline$\% 87.76$ & - & 129 & - & نعم & - \\
\hline$\% 12.24$ & - & 18 & - & كلا & - \\
\hline \%100 & - & 147 & - & & المجموة \\
\hline
\end{tabular}

من خلال الجدول رقم (30) أعلاه والمتعلق بتوزيع

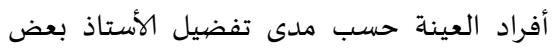
الطلبة على البعض الاخر، تبين لنا أن نسبة الذين

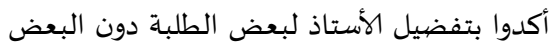
الاخر بلغت 87.76\%، في حين نفت نسبة 12.24\% من الطلبة وجود هذا التفضيل. النتائج العامة للفرضية الثالثة: استناداً الى المعطيات الواردة في الجداول من (18-

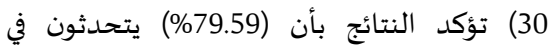
ضرورة النجاح، ومثلت نسبة (80.955\%) من
أفراد العينة أكدوا أن شكر الاستاذ لهم يكون لفظي، بينما نسبة 9.52\% منهم نفت ذلك. جدول (26) يبين توزيع أفراد العينة حسب مدى لينه تحليهم بروح التنافس فيما بينهم

\begin{tabular}{|c|c|c|c|c|}
\hline \multicolumn{2}{|c|}{ النسبة المئوية } & \multicolumn{2}{|c|}{ التكرارات } & الاجابة \\
\hline$\% 72.11$ & - & 106 & - & نعم \\
\hline$\% 27.89$ & - & 41 & - & كلا \\
\hline$\% 100$ & - & 147 & - & المجمموع \\
\hline
\end{tabular}

يبين الجدول أعلاه والخاص بتوزيع أفراد العينة حسب مدى تحليهم بروح التنافس فيما بينهم، بلغت نسبة الذين أكدوا أن لديهم روح التنافس فيما بينهم \%2.11، في حين نسبة الذين أكدوا أن ليس لديهم روح التنافس بينهم 27.89\%

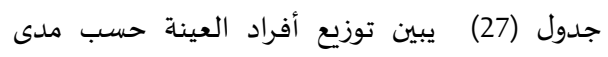

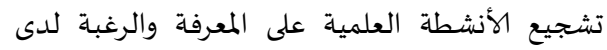

\begin{tabular}{|c|c|c|c|c|c|}
\hline \multicolumn{2}{|c|}{ النسبة المئوية } & \multicolumn{2}{|c|}{ التكرارات } & \multicolumn{2}{|c|}{ الاجابة } \\
\hline \%85.03 & - & 125 & - & نعم & - \\
\hline \%14.97 & - & 22 & - & كلا & - \\
\hline \%100 & - & 147 & - & & \\
\hline
\end{tabular}

استناداً الى الجدول رقم (27) أعلاه والخاص بتوزيع أفراد العينة حسب مدى تشجيع الأنشطة العلمية على الى لئل

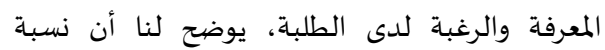

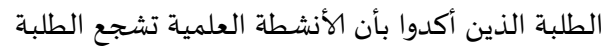

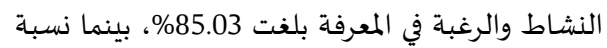

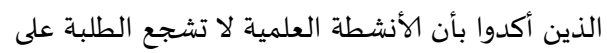

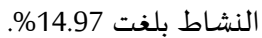
جدول (28) يبين توزيع أفراد العينة حسب مدى لفي تشتت تفكيرهم نتيجة الضوضاء والشغب داخل

\begin{tabular}{|c|c|c|c|c|}
\hline \multicolumn{2}{|c|}{ النسبة المئوية } & & التكرارا & الاجابة \\
\hline$\% 88.44$ & - & 130 & - & نعم \\
\hline$\% 11.56$ & - & 17 & - & كلا \\
\hline$\% 100$ & - & 147 & - & المجموع \\
\hline
\end{tabular}




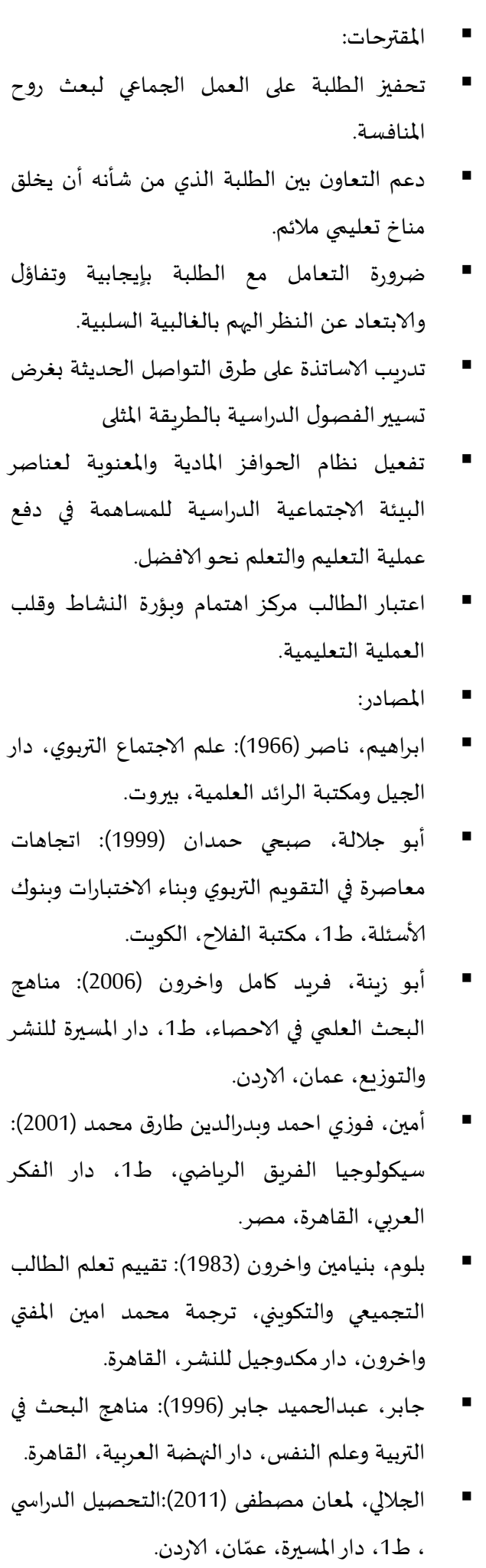

الطلبة يقدمون النصائح لزملائهم من أجل النجاح الدراسي وتعتبر علاقة الطالب بزملائه من العلاقات

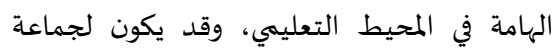
الرفاق تأثير في سلوك الطالب أكثر من تأثير الأمرة

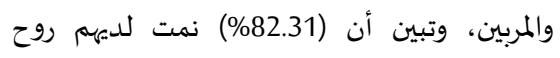

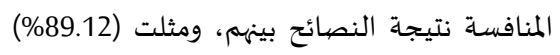
أن التنافس العلمي له دور في خلق الثقة بالنفس،

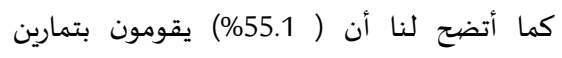
جماعية لبعث روح التنافس ونسبة (60.54\%) من أنسان

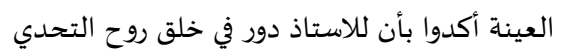

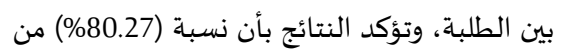
أفراد العينة أن التنافس كجماعة رفاق زاد من التيات مستوى التعليمي لدههم والتشجيع على المعرفة

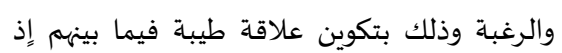
يسعى الطالب الى بث روح التنافس واثارة الدافعية نحو التعليم والوصول الى الهدف وهو النجاح، وأن نسبة (92.77\%) يقوم الاستاذ بشكرهم حيث أن الن الني كلمات الشكر والتشجيع تعزز ثقتهم بنفسهم وهذا

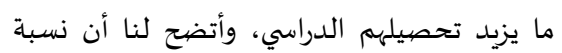

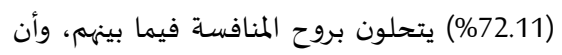
نسبة (85.03\%) من أفراد العينة يؤكدون بأن الانشطة العلمية تشجع الطلبة على النشاط المراد العية وكدون والرغبة في المعرفة وهذا ما ورد في اجابات أسئلة العابة

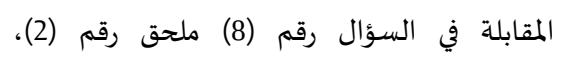
وأوضحت أن نسبة (88.44\%) يتشتت تفكيرهم نتيجة الضيوضاء والشغب داخل القسم، وأن نسبة (82.99\%) يتأثرون عند حصول زملائهم على ألى

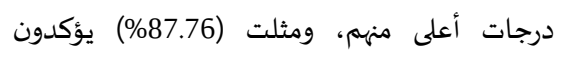
تفضيل الاستاذ بعض الطلبة دون البعض الاخر.

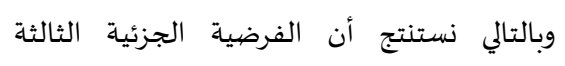

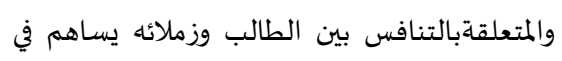

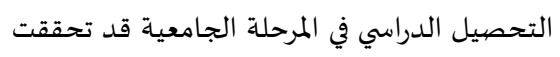

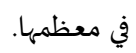
ومنه قبول الفرضية العامة للدراسة: وجود علاقة بين التفاعل الاجتماعي والتحصيل الدراسي. 
صالح، بهجت محمد (1985): عمليات خدمة الجماعة، المكتب الجامعي الحديث، الهكندرية،

الصراف، قاسم (2003):القياس والتقويم في التربية والتعليم، دار الكتاب الحديث، الكويت عبادة، لطيفة (2014): التفاعل الاجتماعي وعلاقته بالتحصيل الدراسي عند التلاميذ، رسالة ماجستير غير منشورة، كلية العلوم الاجتماعية والانسانية،

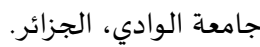
عبدالحفيظ، اخلاص محمد وباهي، مصطفى الجزئر. حسين (2000): طرق البحث العلمي والتحليل الاحصائي، دط، مركز الكتاب للنشر، مصر.

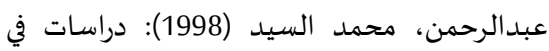
الصحة النفسية، الجزء الثاني، دار فياء للطباعة والنشر، القاهرة.

عبدالهادي، جودة عزة والعزة، سعد سي (2004): مباديء التوجيه والارشاد النفسي، دار الثقافة،

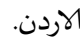

العتوم، عدنان يوسف (2008): علم النفس الاجتماعي، ط4، دار اثراء للنشر والتوزيع، عمان، الاردن. (2)

العتوم، عدنان يوسف (2009): علم النفس الاجتماعي، دار اثراء للنشروالتوزيع، الاردن. العقون، صالح (2011): البيئة الاجتماعية المدرسية وعلاقها بالتحصيل الدراسي، رسالة ماجستير غير منشورة، جامعة محمد خيضر بسكرة، الجزائر. علام، صلاح الدين محمود (2004): التقويم التربوي البديل أسسه النظرية والمنهجية وتطبيقاته الميدانية، ط1، دار الفكر العربي، القاهرة. علي، هنود (2013): التفاعل الاجتماعي وعلاقته بالتحصيل الدراسي لدى بعض تلاميذ التعليم الثانوي، رسالة ماجستير غير منشورة، كلية العلوم الانسانية والاجتماعية، جامعة محمد خيضر

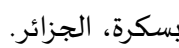

حسن، علاوي محمد (1998): سيكولوجيا الجماعات الرياضية، ط1، مركز الكتاب للنشر،

الدمنهوري، رشاد صالح واخرون (2005): التنشئة

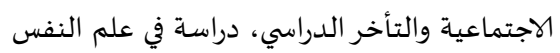

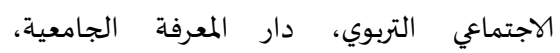
الاسكندرية، مصر. توفيق، مرعي وبلقيس احمد (1984): الميسر في علم

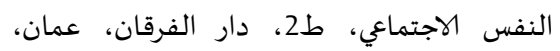

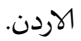

رابح، احمد تركي (1984): مناهج البحث في علوم التربية وعلم النفس، المؤسسة الوطنية للكتاب، الجزائر. سعادة، رشيد (2005): الذكاء الانفعالي وعلاقته بالقيادة التربوية لدى مديري التعليم الإكمالي والثانوي، رسالة ماجستير غير منشورة، جامعة قاصدي مرباح ورقلة، الجزائر. سمارة ، نواف احمد وعبدالسلام موسى العلايلي (2008): مفاهيم ومصططحات في العلوم التربوية، ط1، دار المسيرة للنشروالتوزيع، عمان، الرددن. التل، سيد واخرون (2006): مناهج العلم في التمن البحث العلمي (الاحصاء في البحث العلمي) جامعة عمان العربية للدراسات العلياء، عمان الاردن. شريف، حورية علي (2008): البيئة الاجتماعية

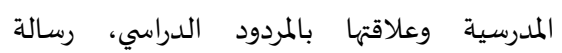
ماجستير غير منشورة، جامعة محمد خيضر بسكرة، الجزائر. الشناوي، احمد واخرون (2001): التنشئة الاجتماعية للطفل، دار الصفاء للنشر والتوزيع، احمدل،

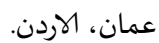
صابر، فاطيمة عوض و حفاجة، ميرفت علي

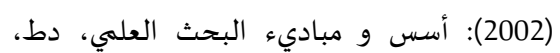

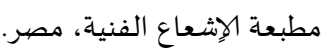



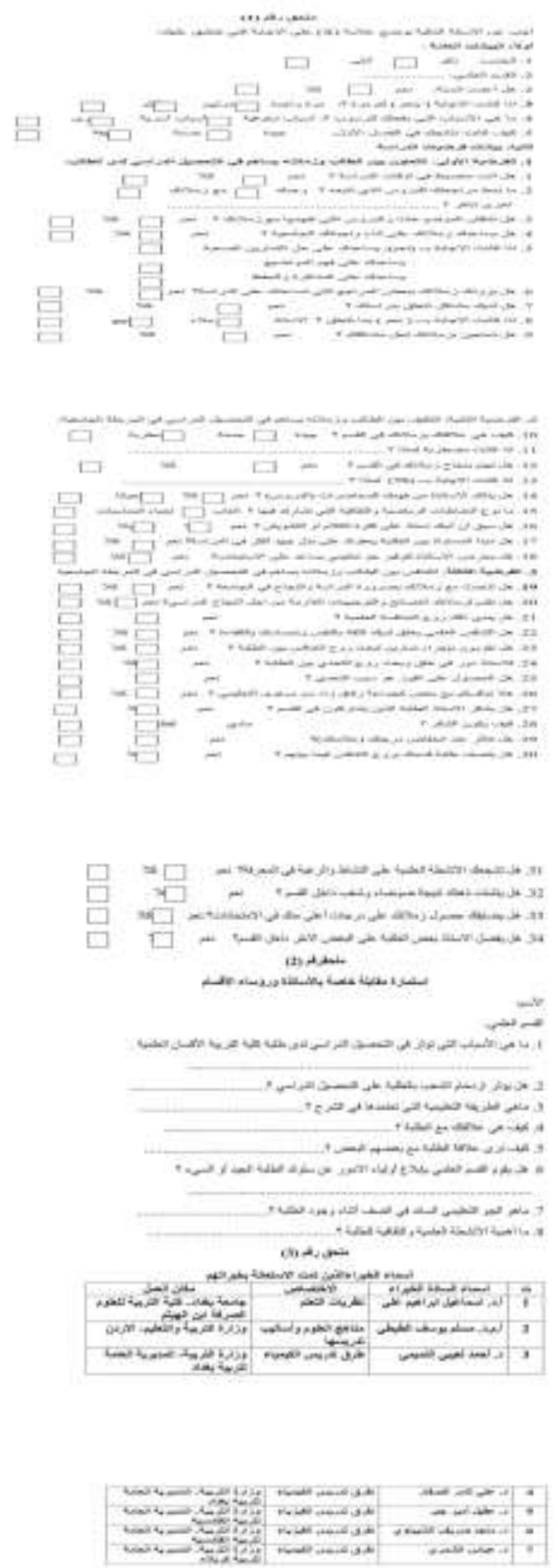

عودة، احمد سليمان (1998): القياس والتقوبم في العملية التربوية، ط2، دار الأمل للنشر والتوزيع، الاردن. العيسوي، عبدالرحمن محمد (2004): علم النفس التربوي، دراسة في التعلم وعادات الاستذكار ومعوقاته، ط1، دار الهضية العربية، بيروت، لبنان. غيث، محمد عاطف (1980): الموقف النظري في علم الاجتماع، دار المعرفة الجامعية، الاككندرية، مصر.

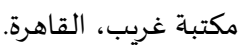
المعايظة، خليل عبدالرحمن (2007): علم النفس الاجتماعي، ط2، دار الفكر، الاردن. ميلود، طبيش (2011): الاتصال التنظيمي وعلاقته بالتفاعل الاجتماعي للعاملين بالمؤسسة، رسالة ماجستير غير منشورة، كلية العلوم الانسانية والاجتماعية، جامعة قاصدي مرباح ورقلة،

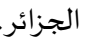
نصر الله، عمر عبدالكريم (2004): تدني مستوى الجمرات التحصيل والانجاز المدرسي، ط1، دار وائل للنشر والتوزيع، الاردن. نصرالدين، جابر والهاشي، لوكبا (2006): مفاهيم أساسية في علم النفس الاجتماعي، دار الهدى للطباعة والنشر، عين مليلة، الجزائر. Malony, (1980): Assessing individuals and stage fright by educational. Test and measurement. New York: little, Brown \& Co. 